$12-2018$

\title{
Straining to Prevent the Rohingya Genocide: A Sociology of Law Perspective
}

Katherine Southwick

National University of Singapore

Follow this and additional works at: https://digitalcommons.usf.edu/gsp

\section{Recommended Citation}

Southwick, Katherine (2018) "Straining to Prevent the Rohingya Genocide: A Sociology of Law Perspective," Genocide Studies and Prevention: An International Journal: Vol. 12: Iss. 3: 119-142. DOI:

https://doi.org/10.5038/1911-9933.12.3.1572

Available at: https://digitalcommons.usf.edu/gsp/vol12/iss3/13

This Articles is brought to you for free and open access by the Open Access Journals at Digital Commons @ University of South Florida. It has been accepted for inclusion in Genocide Studies and Prevention: An International Journal by an authorized editor of Digital Commons @ University of South Florida. For more information, please contact digitalcommons@usf.edu. 


\section{Straining to Prevent the Rohingya Genocide: A Sociology of Law Perspective}

\section{Acknowledgements}

I would like to thank the Centre for Asian Legal Studies at the National University of Singapore's Faculty of Law for its support of previous research into minority rights in Myanmar. I would also like to thank students and faculty at George Mason University's School for Conflict Analysis and Resolution, who provided valuable feedback on an earlier version of this paper. 


\title{
Straining to Prevent the Rohingya Genocide: A Sociology of Law Perspective
}

\author{
Katherine Southwick \\ National University of Singapore \\ Based in Arlington, Virginia
}

This paper analyzes the generally muted international response to the protracted plight of the Rohingya, a persecuted Muslim minority in Myanmar, from a sociology of law perspective. In recent years, some human rights experts and scholars have suggested that the legal terms "crimes against humanity" and "genocide" are applicable to the situation of this minority group. Under international law and practice, such claims implicate obligations to act on the part of the government of Myanmar and the international community. Yet international action on mitigating the risk of crimes against humanity and genocide has arguably been limited.

To help explain this limited international response, this paper draws from and adapts the now classic sociological framework developed by Felstiner, Abel, and Sarat on the emergence and transformation of legal disputes. Following a background section on the Rohingya crisis and relevant international legal frameworks, this paper examines some of the factors that frustrate the processes of naming crimes, blaming perpetrators, and claiming rights and protection for the Rohingya minority in the international context. Work by Bumiller and Edelman concerning models of legal protection, legal ambiguity, and the mediating effects of symbolic structures of compliance augment the analysis. Ambiguity as to when to apply the terms crimes against humanity or genocide, the terms' interrelationship, and the legal and political implications that flow from naming such crimes, feed reluctance to act on the part of other states. A lack of a clear adjudication process further complicates naming, as authority diffuses to a range of institutions or actors who have variable power to name the crimes and determine appropriate actions in response. Competing political and economic considerations obfuscate states' willingness to engage the issue, and certain organizations and bodies are given mandates with limited capacity to enforce those mandates or to submit them to external scrutiny.

Together, these factors combine to portray a weak institutionalization of remedies, a condition which Miller and Sarat have recognized serves to minimize disputing and limit the probability of success. This weak institutionalization of remedies reflects a legal culture in international institutions that is constrained with respect to enforcement. Institutions depend significantly on political will and social consensus. While normative commitments are often invoked, action is subject to the diffusion of responsibility in the naming, blaming, and claiming stages to a range of variously coordinated and politically motivated actors and institutions. This sociological approach thus helps to clarify fundamental constraints on the international legal system in responding to mass violence. It in turn identifies bottlenecks and areas for potential reform, and raises questions as to the uses and limits of law in improving prevention of and protection against mass atrocities.

\section{Background}

The Rohingya Crisis

The Rohingya are a Muslim minority in Myanmar that have primarily lived in Rakhine State bordering Bangladesh in western Myanmar for at least 200 years. ${ }^{1}$ The Myanmar government and others in the country refer to them as "illegal migrants" or "Bengalis," invoking the nineteenth century migration of laborers and merchants from India under British colonial rule. The Rohingya

${ }^{1}$ Martin Smith, "The Muslim Rohingya of Burma," (presentation, Conference of Burma Centrum Nederland, December 11, 1995), n.b. draft only for consultation, accessed December 15, 2017, http://www.netipr.org/policy/ downloads/19951211-Rohingyas-of-Burma-by-Martin-Smith.pdf. Martin claims that while no conclusive studies exist regarding how Rohingya culture arose, what "is absolutely clear is that in Muslim-majority townships of Maungdaw, Buthidaung and Rathedaung in northernmost Arakan [Rakhine State] a distinctive but local Muslim culture has developed over the past two hundred years in which the inhabitants speak a distinctive local dialect which mixes Bengali, Burmese, Hindi and English." The background narrative provided here draws in part from Katherine Southwick, "Preventing Mass Atrocities against the Stateless Rohingya in Myanmar: A Call for Solutions," Columbia Journal of International Affairs 68, no. 2 (Spring/Summer 2015), 139-142. 
were effectively stripped of citizenship under a law enacted in 1982, and for decades, they have suffered discrimination, forced labor, and campaigns of violence largely inflicted by government security forces and ethnic Rakhine Buddhists. ${ }^{2}$

Violence among radical Buddhists in Rakhine State and Rohingya Muslims flared in 2012 and 2013, resulting in over 200 deaths and around 170,000 persons internally displaced. Religious nationalist movements led by Buddhist monks enflamed tensions through hate speech against Muslim minorities. ${ }^{3}$ Many displaced Rohingya were confined to camps and villages where they were required to obtain a permit to leave or seek health care. In July 2012, a United Nations nutrition assessment found that

2,000 children in camps were at a high risk of mortality. A further 9,000 children needed supplementary feeding of some kind, and 2,500 were at risk of acute malnutrition if their needs were not met. Three months later, 2,900 children were estimated to be at a high risk of death, and 14,000 children aged 6 months to 59 months needed supplementary feeding. ${ }^{4}$

Nearly two years later, in February 2014, the government banned Doctors Without Borders, the primary health care provider for the region's one million Rohingya. The organization was forced to leave after assisting victims of a violent assault on a Rohingya village. ${ }^{5}$ A couple weeks later, radical Buddhists, claiming that humanitarian assistance organizations disproportionately favored the Rohingya, raided Red Cross and United Nations aid agencies, forcing over 300 foreign aid workers to evacuate. Some aid workers believed they had been expelled "so there are fewer witnesses to rampant mistreatment and occasional bloodletting." 6 Without outside assistance, speculation mounted that deaths in the displacement camps in particular had sharply increased. ${ }^{7}$

Also in early 2014, the Myanmar government carried out its first census in three decades. Rohingya who wished to be counted were required to register as "Bengalis." In October 2014, the government released its Rakhine State Action Plan, again insisting that Rohingya could apply for citizenship so long as they registered as Bengalis. Those who "refuse to be registered and without adequate documents" would be placed in camps. ${ }^{8}$ Most observers believed this Plan would "entrench discriminatory policies that deprive Rohingya Muslims in Burma of citizenship and lead to forced resettlement." ${ }^{\prime \prime}$ Meanwhile, thousands of Rohingya continued attempting to flee the country every year, often on rickety boats bound for Thailand or Malaysia. Some boats were pushed back to sea and at least hundreds of persons have drowned on the dangerous journeys,

\footnotetext{
${ }^{2}$ Union of Burma, Citizenship Law, Pyithu Hluttaw Law No. 4, 1982.

${ }^{3}$ Thomas Fuller, “Extremism Rises Among Myanmar Buddhists," New York Times, June 20, 2013, accessed November 15, 2018, http://www.nytimes.com/2013/06/21/world/asia/extremism-rises-among-myanmar-buddhists-wary-of-muslimminority.html. Fuller cites anti-Muslim pamphlets distributed by radical monks stating that "Myanmar is facing a most dangerous and fearful poison that is severe enough to eradicate all civilization" and noting that even moderates state they "are afraid of Muslims because their population is increasing so rapidly."

${ }^{4}$ Sarnata Reynolds, "Myanmar Can Keep Rohingya from Starving, but Will It?" CNN World Global Public Square Blog, December 7, 2012, accessed November 15, 2018, http://globalpublicsquare.blogs.cnn.com/2012/12/07/myanmar-cankeep-rohingya-from-starving-but-will-it/.

${ }^{5}$ Jane Perlez, "Death Stalks Muslims as Myanmar Cuts Off Aid," New York Times, May 2, 2014, accessed November 15, 2018, https://www.nytimes.com/2014/05/03/world/asia/death-stalks-muslims-as-myanmar-cuts-off-aid.html.

${ }^{7}$ Ibid. Perlez recounts a case where a baby girl died because the only clinics available to Rohingya either had no medical supplies or were closed and obtaining approval for a permit to visit a local hospital would have taken too long, if it would have been received at all.

${ }^{8}$ Jared Ferrie, “US Says Myanmar Should Draft New Plan to Give Rohingya Citizenship," Reuters, November 13, 2014, accessed November 15, 2018, https://www.reuters.com/article/us-myanmar-rohingya/u-s-says-myanmar-shoulddraft-new-plan-to-give-rohingya-citizenship-idUSKCN0IX0LE20141113. Ferrie also reports that the U.S. has "urged Myanmar to draft a new plan to allow the ethnic Rohingya minority to become citizens and to scrap proposed plans to send them to detention camps."

${ }^{9}$ Human Rights Watch, “Burma: Government Plan Would Segregate Rohingya," October 3, 2014, accessed November 15, 2018, http://www.hrw.org/news/2014/10/03/burma-government-plan-would-segregate-rohingya.
} 
while those Rohingya that reached land are sometimes held in crowded detention centers. ${ }^{10}$

The latest round of violence against the Rohingya was sparked on August 25, 2017, when the militant group Arakan Rohingya Salvation Army (ARSA) attacked 30 police posts and an army base in Rakhine State. ARSA first appeared in late 2016, when its October 9, 2016 attack on three border posts left nine security officers dead and provoked a counteroffensive that displaced around 100,000 people. Since the latest August 2017 attack and military counteroffensive, more than 730,000 Rohingya have fled the country and crossed into Bangladesh, ${ }^{11}$ joining more than 200,000 Rohingya who previously fled over the past three decades. ${ }^{12}$ An estimated 30,000 non-Muslim civilians were internally displaced within two weeks of the attack. ${ }^{13}$ Roughly half a million Rohingya are thought to remain in Myanmar, largely cut off from humanitarian assistance. ${ }^{14}$ Human rights organizations have documented the burning of Rohingya villages across three townships in Rakhine State. ${ }^{15}$ Many Rohingya have shared testimony of atrocities perpetrated by the Myanmar military and Rakhine Buddhist groups, including gang rapes and indiscriminate murder of men, women, and children. ${ }^{16}$ Throughout their time in Bangladesh, Rohingya refugees have had almost no access to jobs, services, or citizenship. ${ }^{17}$

The last few years of persecution of and violence against the Rohingya have transpired in the context of significant national reform. After almost half a century of authoritarianism, the government ostensibly began a democratic transition in 2011. It allowed for parliamentary elections, released political prisoners including Nobel Laureate and political opposition leader Aung San Suu Kyi, and restored some civil and political rights. The government also took steps to end armed conflict with some of the country's largest ethnic groups. In April 2013, the European Union expressed its validation of these reforms when it lifted nearly all of its economic and individual sanctions against Myanmar. It kept in place an arms embargo, pending improvements in the treatment of minority Muslims. ${ }^{18}$ In October 2016, the U.S. also lifted most sanctions in order "to support efforts by the civilian government and the people of Burma to continue their process of political reform and broad-based economic growth and prosperity." ${ }^{19}$ Foreign aid and investment, largely from within Asia, dramatically increased, and was valued at almost USD2 billion in $2013 .{ }^{20}$

${ }^{10}$ IRIN, “Analysis: In Search of a Regional Rohingya Solution," July 26, 2013, accessed November 15, 2018, http://www. irinnews.org/report/98477/analysis-in-search-of-a-regional-rohingya-solution.

${ }^{11}$ United Nations High Commissioner for Refugees (UNHCR), “Operational Update: Bangladesh,” October 16-31, 2018, accessed November 19, 2018, http://reporting.unhcr.org/sites/default/files/UNHCR\%20Bangladesh\%20-\%20 Operational\%20Update\%20-\%2016-310CT18.pdf.

${ }^{12}$ International Organization of Migration, "IOM Bangladesh: Rohingya Humanitarian Crisis Response External Report," October 19-25, 2018, accessed November 18, 2018, https://www.iom.int/sites/default/files/situation reports/file/ bangladesh sr 20181019-25.pdf.

${ }^{13}$ Andrew R.C. Marshall and Krishna Das, "Rohingya Insurgents Declare Temporary Ceasefire Amid Humanitarian Crisis," Reuters, September 9, 2017, accessed November 19, 2018, https://www.reuters.com/article/us-myanmarrohingya/rohingya-insurgents-declare-temporary-ceasefire-amid-humanitarian-crisis-idUSKCN1BK07T.

${ }^{14}$ Max Bearak, "Bangladesh Is Now Home to Almost 1 Million Rohingya Refugees," Washington Post, October 25, 2017, accessed November 15, 2018, https://www.washingtonpost.com/news/worldviews/wp/2017/10/25/bangladesh-is-nowhome-to-almost-1-million-rohingya-refugees/?utm term=.db5f3fef4e8f.

${ }^{15}$ Human Rights Watch, "Burma: Satellite Imagery Shows Mass Destruction," September 19, 2017, accessed November 15, 2018, https://www.hrw.org/news/2017/09/19/burma-satellite-imagery-shows-mass-destruction.

${ }^{16}$ Rachael Revesz, “Doctors Report Horrifying Gang Rape Attacks on Rohingya Women,” The Independent, September 25, 2017, accessed November 15, 2018, http://www.independent.co.uk/news/world/asia/doctors-un-rohingya-muslimwomen-refugees-burma-rape-sexual-violence-a7965251.html; Jeffrey Gettleman, "Rohingya Recount Atrocities: They Threw My Baby Into a Fire," New York Times, October 11, 2017, accessed November 15, 2018, https://www.nytimes. com/2017/10/11/world/asia/rohingya-myanmar-atrocities.html?r=0.

${ }^{17}$ Sean Garcia and Camilla Olson, Rohingya: Burma's Forgotten Minority (Refugees International, December 18, 2008), accessed November 18, 2017, http://www.refworld.org/docid/494f53e72.html.

${ }^{18}$ Fergal Keane, "EU Lifts Sanctions against Burma," BBC News Europe, April 22, 2013, accessed November 15, 2018, http:// www.bbc.com/news/world-asia-22254493.

${ }^{19}$ U.S. Embassy in Burma, “U.S. Treasury Department Office of Public Affairs: Treasury Implements Termination of Burma Sanctions Program," October 7, 2016, accessed November 18, 2018, https://mm.usembassy.gov/terminationburma-sanctions-program/.

${ }^{20}$ Aung Hla Tun and Jared Ferrie, “Foreign Investment in Myanmar Surges, Office Rents Sizzle," Reuters, September 
Investment from American and European companies has grown increasingly uncertain, however, partly as a result of large-scale violence in Rakhine and the increased willingness of the US and the EU to reimpose sanctions against military leaders. ${ }^{21}$

In November 2015, Aung San Suu Kyi's political party, the National League for Democracy, won a landslide victory in the country's first openly contested parliamentary elections in 25 years. Under the 2008 Constitution, a quarter of seats in Parliament are held by the military, enabling it to veto constitutional amendments. Because Aung San Suu Kyi has immediate family with nonBurmese citizenship - her sons are British citizens - she could not become president, though she has operated as the government's de facto leader under the title of State Counselor. The military, which operates independently of the civilian government, retains control over the ministries of defense, border, and home affairs.

The post-August 2017 round of violence against the Rohingya, which is said to have caused the largest and fastest exodus of people since the 1994 Rwandan genocide, has attracted more international attention than past instances of persecution and displacement. ${ }^{22}$ On September 11, 2017, the United Nations High Commissioner for Human Rights called this latest campaign a "textbook example of ethnic cleansing." ${ }^{23}$ In October 2017, the United States government suspended military assistance to Myanmar units linked to violence against the Rohingya. ${ }^{24}$ The United Kingdom and European Union similarly reduced military relations with Myanmar at this time. ${ }^{25}$ Then U.S. Secretary of State Rex Tillerson declared that the international community could not "be witness to the atrocities that have been reported." ${ }^{26}$ A U.S. State Department spokesperson stated that, "It is imperative that any individuals or entities responsible for atrocities, including non-state actors and vigilantes, be held accountable." ${ }^{\prime 2}$ Also in October 2017, U.S. Senator Ben Cardin of Maryland characterized the Myanmar government's response as genocide. ${ }^{28}$ Together with the late U.S. Senator John McCain, Senator Cardin proposed legislation to impose sanctions and travel restrictions on senior Myanmar military officials deemed to be responsible for atrocities. ${ }^{29}$ The Senate Foreign Relations Committee passed the legislation in February 2018 for consideration by the whole Senate. According to a December 2017 report, "Doctors Without Borders has called the camps in Bangladesh a 'time bomb ticking toward a full-blown health crisis' as sanitation and medical services and distribution of clean water have struggled to keep up with refugee arrivals." ${ }^{30}$

20, 2013, accessed November 20, 2018, http://www.reuters.com/article/2013/09/20/myanmar-investmentidUSL3N0HG0L420130920.

${ }^{21}$ Yigal Chazan, "Foreign Investors Jittery Amid Myanmar's Rohingya Crisis," The Diplomat, October 21, 2017, accessed November 18, 2018, https://thediplomat.com/2017/10/foreign-investors-jittery-amid-myanmars-rohingya-crisis/.

22 "The Rohingya Refugee Crisis Is the Worst in Decades," The Economist, September 21, 2017, accessed November 18, 2018, https://www.economist.com/blogs/graphicdetail/2017/09/daily-chart-13.

${ }^{23}$ Zeid Ra'ad Al Hussein, “Darker and More Dangerous: High Commissioner Updates the Human Rights Council on Human Rights Issues in 40 Countries," (opening statement, Geneva, September 11, 2017), United Nations Human Rights Council, accessed November 15, 2018, http://www.ohchr.org/EN/NewsEvents/Pages/DisplayNews. aspx?NewsID=22041\&LangID=E.

24 "US Withdraws Assistance from Myanmar Military Amid Rohingya Crisis," The Guardian, October 24, 2017, accessed November 18, 2018, https:/www.theguardian.com/world/2017/oct/24/us-withdraws-assistance-from-myanmarmilitary-amid-rohingya-crisis.

25 "EU to Scale Back Relations with Myanmar's Military," Financial Times, October 16, 2017, accessed November 18, 2018, https://www.ft.com/content/cf0b94f6-b25d-11e7-a398-73d59db9e399.

26 “U.S. Says Hold Myanmar Military Leaders Accountable in Rohingya Crisis," Reuters, October 18, 2017, accessed November 18, 2018, http://www.reuters.com/article/us-myanmar-rohingya-tillerson/u-s-says-holds-myanmarmilitary-leaders-accountable-in-rohingya-crisis-idUSKBN1CN289.

${ }^{27}$ Ibid.

${ }^{28}$ United States Senator Ben Cardin, “Cardin Labels Burmese Rohingya Crisis 'Genocide,' Presses Administration for Answers," (press statement, October 24, 2017), accessed December 15, 2017, https://www.cardin.senate.gov/ newsroom/press/release/cardin-labels-burmese-rohingya-crisis-genocide-presses-administration-for-answers.

${ }^{29}$ United States Senator Ben Cardin, “Cardin, McCain Bill on Burma Accountability Passes Senate Foreign Relations Committee," (press release, February 7, 2018), accessed November 16, 2018, https://www.cardin.senate.gov/ newsroom/press/release/cardin-mccain-bill-on-burma-accountability-passes-senate-foreign-relations-committee.

${ }^{30}$ Bearak, Bangladesh Is Now Home. 
In December 2017, the U.S. government imposed sanctions on General Maung Maung Soe, who oversaw the military crackdown against the Rohingya minority. ${ }^{31}$ In June 2018, Canada and the European Union sanctioned seven senior military leaders. ${ }^{32}$ The U.S. sanctioned four more commanders and two military units in August 2018. ${ }^{33}$ This decision almost coincided with the September 2018 release of a U.S. State Department report documenting widespread, systematic attacks and atrocities committed largely by the Myanmar military in the past two years. The report was based on an April 2018 survey of more than 1,000 Rohingya refugees living in camps in Bangladesh. ${ }^{34}$ Around the same time, an international independent fact-finding mission on Myanmar established by the United Nations Human Rights Council released its own report. Among its recommendations was a call for the United Nations to refer the situation of the Rohingya, as well as violence in Shan and Kachin States, to the International Criminal Court or other ad hoc international criminal tribunal. The report called for investigation and prosecution of senior military officials for war crimes, crimes against humanity, and genocide..$^{35}$ The fact-finding mission's detailed findings were published in a separate 444-page report. ${ }^{36}$ On September 6, 2018, in response to a request from the Prosecutor of the International Criminal Court (ICC) to clarify the court's scope of jurisdiction, ICC Pre-Trial Chamber I ruled that it could exercise jurisdiction with regard to crimes within its jurisdiction, such as deportation and other crimes against humanity, provided that they were committed on the territory of a State that is party to the Rome Statute, such as Bangladesh. ${ }^{37}$ The ruling prompted the Chief Prosecutor Fatou Bensouda to begin investigating whether evidence is sufficient to file charges against alleged perpetrators. ${ }^{38}$

\section{International Legal Frameworks: Crimes against Humanity and Genocide}

Over the years and regarding the more recent attacks, various entities have applied the legal labels of crimes against humanity and genocide to the situation of the Rohingya. Scholars and human rights organizations, such as the Irish Centre for Human Rights and Human Rights Watch, have characterized the plight of the Rohingya as crimes against humanity. ${ }^{39}$ Under the Rome Statute of the International Criminal Court, of which 122 countries (excluding Myanmar) are States Parties, a "crime against humanity" means any of the enumerated acts in Article 7(1) "when committed as part of a widespread or systematic attack directed against any civilian population, with knowledge

${ }^{31}$ Susan Heavey and Arshad Muhammad, "U.S. Sanctions Myanmar General Accused of Carrying Out Ethnic Cleansing Campaign Against Rohingya," Time, December 22, 2017, accessed November 16, 2018, http://time.com/5077015/ussanctions-rights-abusers-myanmar-general/.

${ }^{32}$ Conor Finegan, “When Europe, Canada Slapped New Sanctions on Myanmar over Rohingya Treatment, Where Was US?" ABC News, July 8, 2018, accessed November 16, 2018, https://abcnews.go.com/International/europe-canadaslapped-sanctions-myanmar-rohingya-treatment-us/story?id=56441577.

${ }^{33}$ United States Department of the Treasury Press Release, "Treasury Sanctions Commanders of the Burmese Security Forces for Serious Human Rights Abuses," August 17, 2018, accessed November 16, 2018, https://home.treasury.gov/ news/press-releases/sm460.

${ }^{34}$ United States Department of State, Documentation of Atrocities in Northern Rakhine State, August 2018, accessed November 16, 2018, https://www.state.gov/documents/organization/286307.pdf.

${ }^{35}$ United Nations Human Rights Council, Report of the international fact-finding mission on Myanmar, September 12, 2018, (UN Doc. A/HRC/39/64), paras. 87-89, 105, accessed November 16, 2018, https://documents-dds-ny.un.org/doc/ UNDOC/GEN/G18/274/54/PDF/G1827454.pdf?OpenElement.

${ }^{36}$ United Nations Human Rights Council, Report of the Detailed Findings of the Independent International Fact-Finding Mission on Myanmar, September 17, 2018 (UN Doc. A/HRC/39/CRP.2), accessed November 16, 2018, https://www.ohchr.org/ Documents/HRBodies/HRCouncil/FFM-Myanmar/A HRC 39 CRP.2.pdf.

${ }^{37}$ Decision on the 'Prosecution's Request for a Ruling on Jurisdiction under Article 19(3) of the Statute, Pre-Trial Chamber I, September 6, 2018, No. ICC-RoC46(3)-01/18, paras. 73-74.

${ }^{38}$ International Criminal Court, Office of the Prosecutor, "Statement of ICC Prosecutor, Mrs. Fatou Bensouda, on opening a Preliminary Examination concerning the alleged deportation of the Rohingya people from Myanmar to Bangladesh," (statement, The Hague, September 18, 2018), accessed November 16, 2018, https://www.icc-cpi.int/ Pages/item.aspx?name=180918-otp-stat-Rohingya.

${ }^{39}$ Irish Centre for Human Rights, Crimes against Humanity in Western Burma: The Situation of the Rohingyas (Galway: NUI Galway, 2010); Human Rights Watch, All You Can Do is Pray: Crimes against Humanity and Ethnic Cleansing of Rohingya Muslims in Burma's Arakan State (HRW, 2013). 
of the attack." 40 Some of the acts include murder, forcible transfer of population, torture, rape, persecution, or other inhumane acts causing serious bodily or mental harm. ${ }^{41}$ On the application of crimes against humanity to the situation of the Rohingya, experts have shared a general consensus for several years.

Within the last few years, a growing number of experts and organizations also asserted that the Rohingya community faced a high risk of genocide or that genocide was and continues to be already under way. ${ }^{42}$ In addition to killing and causing serious bodily or mental harm to members of the group, among the acts that can constitute genocide under Article 2 of the 1948 Convention is "[d]eliberately inflicting on the group conditions of life calculated to bring about [the group's] physical destruction in whole or in part." ${ }^{43}$ Such conditions could include, but are not limited to, "subjecting the group to a subsistence diet, systematic expulsion from homes and denial of medical services. Also included is the creation of circumstances that would lead to a slow death, such as lack of proper housing, clothing and hygiene or excessive work or physical exertion." ${ }^{44}$ As the International Court of Justice has elaborated, a key feature of the crime of genocide is the intent requirement, that the acts are committed not only deliberately and unlawfully, but with "intent to destroy" a racial or religious group, "as such." This requirement is also referred to as a "specific intent" to destroy a protected group. ${ }^{45}$ Proving genocidal intent carries a high burden of proof, as "claims against a State involving charges of exceptional gravity must be proved by evidence that is fully conclusive." 46

Reviewing the elements of this crime suggests that the possibility of genocide could be seriously considered to describe the plight of the Rohingya over the past several years ${ }^{47}$ The attacks on Rohingya villages, mass arrests and murder of men and boys, allegations of gang rape, travel restrictions, denationalization and denial of the group's cultural identity, deprivation of access to health care and food, particularly high starvation rates among small children, hate speech, and mass displacement could plausibly constitute a cluster of facts from which genocidal intent could be inferred. ${ }^{48}$ In identifying genocidal intent, the UN's August 2018 fact-finding mission report highlighted "the broader oppressive context and hate rhetoric; specific utterances of commanders and direct perpetrators; exclusionary policies, including to alter the demographic composition of Rakhine State; the level of organization indicating a plan for destruction; and the scale and brutality of the violence committed." 49

${ }^{40}$ United Nations General Assembly (UNGA), Rome Statute of the International Criminal Court, July 17, 1998, (UN Doc. A/ CONF.183/9), article 7, accessed December 6, 2018, https://www.icc-cpi.int/nr/rdonlyres/ea9aeff7-5752-4f84-be940a655eb30e16/0/rome statute english.pdf.

${ }^{41}$ Ibid., art. 7(1).

${ }^{42}$ Maung Zarni and Alice Cowley, "The Slow-Burning Genocide of Myanmar's Rohingya," Pacific Rim Law and Policy Journal 23, no. 3 (June 2014), 683; Geoffrey Nice and Francis Wade, "Preventing the Next Genocide," Foreign Policy, May 12, 2014. Nice is a former prosecutor at the International Criminal Tribunal for the former Yugoslavia; Katherine G. Southwick, "Looming Genocide in Myanmar - And the Silence that Greets It," Talking Points Memo, June 12, 2014, accessed November 18, 2018, http://talkingpointsmemo.com/cafe/looming-genocide-in-myanmar-and-the-silence-thatgreets-it; Kate Cronin-Furman, "Calling a Genocide a Genocide," Slate, October 31, 2017, accessed November 18, 2018, http://www.slate.com/articles/news and politics/foreigners/2017/10/the word genocide is overused but it applies to what $\mathrm{s}$ happening to the.html.

${ }^{43}$ United Nations, General Assembly Resolution 260, Convention on the Prevention and Punishment of the Crime of Genocide, December 9, 1948, (UN Doc. A/RES/260(III)), article 2(c).

${ }^{44}$ Prosecutor v. Milomir Stakic, International Criminal Tribunal for the former Yugoslavia, Trial Chamber II, July 31, 2003, IT-97-24-T, para. 507.

${ }^{45}$ Bosnia and Herzegovina v. Serbia and Montenegro, Case Concerning Application of the Convention on the Prevention and Punishment of the Crime of Genocide, Judgment, ICJ Reports 2007, para. 187.

${ }^{46}$ Ibid., 209.

${ }^{47}$ Southwick, Preventing Mass Atrocities, 144; Katherine Southwick, “Confronting Genocide in Myanmar: The Urgent Need to Prevent and Protect," Policy Forum, December 2, 2016, accessed November 18, 2018, https://www.policyforum.net/ confronting-genocide-myanmar/.

${ }^{48}$ William Schabas, Genocide in International Law (Cambridge: Cambridge University Press, 2000), 219-225. Schabas reviews international criminal jurisprudence to discuss how courts can infer genocidal intent from factual circumstances of a case, such as the systematic or targeted nature of attacks, use of racist rhetoric, or scale of atrocities.

${ }^{49}$ United Nations Human Rights Council, Report of the international fact-finding mission on Myanmar, para. 85. 
Yet even in 2013, before this latest round of mass violence, genocide scholar William Schabas said, "We're moving into a zone where the word can be used in the case of the Rohingya. When you see measures preventing births, trying to deny the identity of a people, hoping to see that they ... no longer exist ... these are all warning signs that mean it's not frivolous to envisage the use of the term genocide." ${ }^{50}$ The Canada-based Sentinel Project for Genocide Prevention asserted in 2013 that interethnic violence in Rakhine State "is part of a state-sponsored campaign of ethnic cleansing with the distinct possibility of genocide carried out either through extermination by killing squads or more slowly by isolation and starvation." ${ }^{51}$ In 2014, the U.S. Holocaust Memorial Early Warning Project identified Myanmar as the country at greatest risk of state-led mass killing. ${ }^{52}$ In 2015, Yale Law School's human rights clinic determined that there was "strong evidence" of genocide against the Rohingya population of Myanmar..$^{53}$ The same year, the International State Crime Initiative (ISCI) of Queen Mary University of London published a report, Countdown to Annihilation: Genocide in Myanmar, which concluded according to social scientific frameworks that genocide was taking place against the Rohingya. ${ }^{54}$ According to Dr. Penny Green of ISCI, the violence following the August 2017 attacks by Rohingya militants on Myanmar border posts pointed to a "disturbing yet entirely predictable escalation in the genocidal process." ${ }^{55}$ In November 2017, Fortify Rights and the Simon Skojt Center at the U.S. Holocaust Memorial Museum released a report expressing serious concern about "growing evidence of genocide against Rohingya Muslims." ${ }^{56}$ While they found that further investigation would be necessary in order to ascertain genocidal intent, they emphasized that the Myanmar government and the international community "should not wait for a formal legal determination of genocide to take immediate action." ${ }^{57}$ Fortify Rights released a lengthy report in July 2018 documenting "extensive and systematic preparations" on the part of Myanmar authorities to carry out atrocities amounting to crimes against humanity and genocide in the weeks and months prior to the August 25, 2017 attacks by a Rohingya militant group. ${ }^{58}$

Up until late 2017, neither foreign governments nor the United Nations had officially used the term, "genocide," in connection with the Rohingya. In April 2014, speaking in his personal capacity, the then former UN Special Rapporteur for Human Rights, Tomás Ojéa Quintana, said at a conference: "There are elements of genocide in Rakhine with respect to Rohingyas ... The possibility of genocide needs to be discussed. I myself do not use the term genocide for strategic reasons." ${ }^{59}$ In 2014, in a public letter to then U.S. Secretary of State John Kerry, 72 Members of

50 "Expert Warns of Rohingya Genocide," Al Jazeera, March 3, 2013, accessed November 18, 2018, http://www.aljazeera. com/pressoffice/2013/03/20133210535530465.html.

${ }^{51}$ Sentinel Project for Genocide Prevention, Burma Risk Assessment, September 2013, 3, accessed November 18, 2018, http://thesentinelproject.org/wp-content/uploads/2013/09/Risk-Assessment-Burma-September-2013.pdf.

${ }^{52}$ Jay Ulfelder, "2014 Statistical Risk Assessments," U.S. Holocaust Memorial Museum Early Warning Project, July 31, 2014, accessed November 18, 2018, http://cpgearlywarning.wordpress.com/2014/07/31/2014-statistical-riskassessments/.

${ }^{53}$ Allard K. Lowenstein International Human Rights Clinic, Persecution of the Rohingya Muslims: Is Genocide Occurring in Myanmar's Rakhine State? A Legal Analysis (New Haven: Yale Law School, October 2015), 64 accessed November 18, 2018, http://www.fortifyrights.org/downloads/Yale Persecution of the Rohingya October 2015.pdf.

${ }^{54}$ Penny Green, et al., Countdown to Annilation: Genocide in Myanmar (London: Queen Mary University of London, School of Law, International State Crime Initative, 2015), accessed November 18, 2018, http://statecrime.org/data/2015/10/ ISCI-Rohingya-Report-PUBLISHED-VERSION.pdf.

${ }^{55}$ ISCI, "Genocide of Rohingya in Myanmar May Be Entering New and Deadly Phase," (press release, October 14, 2017), accessed November 16, 2018, http://statecrime.org/state-crime-research/isci-press-release-genocide-of-rohingya-inmyanmar-may-be-entering-new-and-deadly-phase/.

${ }^{56}$ Fortify Rights and Simon Skjodt Center for the Prevention of Genocide, United States Holocaust Memorial Museum, "They Tried to Kill Us All": Atrocity Crimes against Rohingya Muslims in Rakhine State, Myanmar, November 2017, accessed November 16, 2018, https://www.ushmm.org/m/pdfs/201711-atrocity-crimes-rohingya-muslims.pdf.

${ }^{57}$ Ibid.

${ }^{58}$ Fortify Rights, They Gave Them Long Swords: Preparations for Genocide and Crimes against Humanity Against Rohingya Muslims in Rakhine State, Myanmar, July 2018, accessed November 16, 2018, https://www.fortifyrights.org/downloads/ Fortify Rights Long Swords July 2018.pdf.

${ }^{59}$ Maung Zarni, featuring Tomás Ojéa Quintana, “UN's Quintana: 'elements of genocide' against Myanmar's Rohingya," (remarks, London Conference on Decades of Persecution and Destruction of Myanmar's Rohingya, London, April 28, 2014), accessed November 18, 2018, https://www.youtube.com/watch?v=Mpn5Amp ZfQ. 
the U.S. Congress expressed deep concern about "horrific images of emaciated children ... from Rakhine State in western Burma, where [violently displaced Rohingya] have been confined in what some are calling concentration camps." ${ }^{\prime 0}$ Based on these and other human rights concerns, they requested the Secretary to "undertake a significant recalibration of U.S. policy" toward Myanmar. ${ }^{61}$

Official references to genocide begin to appear in the autumn of 2017, after the scale of killings and mass displacement had reached the highest levels in the recent history of Rakhine State. In September 2017, French President Emmanuel Macron asserted that attacks against Rohingya constituted genocide. ${ }^{62}$ In December, at a special session of the UN Human Rights Council, the UN High Commissioner for Human Rights, Zeid Ra'ad al-Hussein, asked with respect to Myanmar, "Can anyone, can anyone, rule out that elements of genocide may be present?" 63 As noted, U.S. Senator Cardin referred to the crisis in October 2017 as genocide, prompting the Senate Foreign Relations Committee of the U.S. Congress to craft legislation imposing sanctions on top Myanmar military leaders. At the same time, the U.S Secretary of State reportedly weighed whether to refer to events as "ethnic cleansing," which is not a legal term of art, but which would signal a political willingness to take more action regarding the crisis. ${ }^{64}$ The same question arose with respect to the August 2018 U.S. State Department report, which media outlets cited as having "stopped short" of calling the violence genocide or crimes against humanity. ${ }^{65}$ Apparently, whether or not to use these terms was intensely debated internally, delaying the report's release. ${ }^{66}$ Notwithstanding the labels' absence, U.S. officials said that the report could justify punitive actions such as further sanctions against Myanmar leaders. ${ }^{67}$ Following the report's release, the U.S. also doubled its humanitarian aid for the crisis, pledging an additional US\$185 million to assist Rohingya in Bangladesh and Myanmar. ${ }^{68}$

Crimes against humanity and genocide ostensibly trigger legal obligations on the part of the international community to act to protect threatened communities. Under the principle of Responsibility to Protect, when a state fails to protect its populations from these crimes, the international community must be "prepared to take collective action, in a timely and decisive manner, through the Security Council, in accordance with the Charter [of the United Nations]." ${ }^{69}$ Under the 1948 Convention on the Prevention and Punishment of the Crime of Genocide, parties "undertake to prevent and punish" genocide. Perpetrators "shall be tried by a competent tribunal"70 and "shall be punished." ${ }^{\prime 11}$ Furthermore, "Any Contracting Party may call upon the competent organs of the United Nations to take such action under the Charter of the United Nations as they consider

${ }^{60}$ Congress of the United States, Letter from Various U.S. Members of Congress to U.S. Secretary of State John Kerry, July 31, 2014, 2, accessed December 18, 2017, http://www.burmapartnership.org/wp-content/uploads/2014/08/Letter-fromMembers-of-the-US-Congress-to-Secretary-of-State-John-Kerry.pdf.

${ }^{61}$ Ibid.

62 “Attacks on Myanmar's Rohingya 'Genocide' - Macron," RTE, September 21, 2017, accessed November 19, 2018, https:// www.rte.ie/news/2017/0921/906399-rohingya/.

${ }^{63}$ Nick Cumming-Bruce, "Myanmar's Rohingya Actions May be Genocide, U.N. Official Says," New York Times, December 5, 2017, accessed November 19, 2018, https://www.nytimes.com/2017/12/05/world/asia/myanmar-rohingya-genocideun.html? $\mathrm{r}=0$.

${ }^{64}$ Patrick Zengerle and Matt Spetalnick, “US Weighs Calling Myanmar's Rohingya Crisis 'Ethnic Cleansing,"' Reuters, October 25, 2017, accessed November 18, 2018, https://uk.reuters.com/article/uk-myanmar-rohingya-usa/u-s-weighscalling-myanmars-rohingya-crisis-ethnic-cleansing-idUKKBN1CT2RT.

${ }^{65}$ Eli Meixler, "U.S. Report on Rohingya Stops Short of Calling Myanmar's 'Coordinated' Violence Genocide," Time, September 25, 2018, accessed November 16, 2018, http://time.com/5405378/state-department-myanmar-rohingyareport/.

${ }^{66}$ Matt Spetalnick and Jason Szep, “U.S. Accuses Myanmar Military of 'Planned and Coordinated' Rohingya Atrocities," Reuters, September 24, 2018, accessed November 16, 2018, https://www.reuters.com/article/us-myanmar-rohingya-usaexclusive/exclusive-myanmar-military-coordinated-atrocities-against-rohingya-u-s-report-idUSKCN1M42DY.

${ }^{67}$ Ibid.

${ }^{68}$ Meixler, US Report on Rohingya Stops Short.

${ }^{69}$ United Nations General Assembly (UNGA), Resolution 60/1, 2005 World Summit Outcome, October 24, 2005 (UN Doc. A/ RES/60/1), para. 139, accessed November 16, 2018, http://www.un.org/womenwatch/ods/A-RES-60-1-E.pdf.

${ }^{70} \mathrm{UN}$, Convention on the Prevention and Punishment of the Crime of Genocide, article 6.

${ }^{71}$ Ibid., art. 5. 
appropriate for the prevention and suppression of acts of genocide." ${ }^{72}$ The ICC's Rome Statute affirms that these crimes are "the most serious crimes of concern to the international community as a whole." Additionally, they "must not go unpunished and [] their effective prosecution must be ensured by taking measures at the national level and by enhancing international cooperation."73 The ICC may exercise jurisdiction over the crimes of war crimes, crimes against humanity, and genocide on the basis of a referral of a plausible case to the Prosecutor from a State Party or the Security Council, or if the Prosecutor initiates an investigation. ${ }^{74}$ While Myanmar is not a State Party to the Rome Statute, it may accept jurisdiction in individual cases. ${ }^{75}$

The UN Special Adviser on the Prevention of Genocide and the UN Special Adviser on the Responsibility to Protect have complementary mandates to "alert relevant actors to the risk of genocide, war crimes, ethnic cleansing and crimes against humanity, enhancing the capacity of the United Nations to prevent these crimes . . . and engage with Member States, regional [] arrangements, and civil society to develop more effective means of response when they do occur." ${ }^{176}$ Public statements from these offices on the Rohingya and Muslim minorities have been scarce in the past few years. A March 2013 statement by the Special Adviser on the Prevention of Genocide raised concerns about the spread of sectarian violence following anti-Muslim violence in Meiktila. ${ }^{77}$ In September 2017, the same official stated that violence against the Rohingya "could be ethnic cleansing and could amount to crimes against humanity." 78 Further, "In fact it can be the precursor to all the egregious crimes - and I mean genocide. We are not yet there, we cannot say we are facing a genocide, but it is time to take action. ${ }^{\prime 79}$ During a week-long visit to the refugee camps in Bangladesh in March 2018, the Special Representative asserted that international crimes had been committed, but that it would be up to a court to make a final determination as to whether the atrocities constituted genocide. ${ }^{80}$

\section{Naming, Blaming, and Claiming Genocide}

Despite the existence of relevant laws and legal obligations to act, steps to address the protracted and worsening plight of the Rohingya have been limited and slow to emerge, both before the August 2017 attacks and afterwards. In seeking to help understand why international law and institutions have not been effective, the approach here is to adapt certain sociology of law frameworks into a lens through which to view and assess international responses as a legal process. Specifically, insights are drawn from Felstiner et al.'s framework to describe the emergence and transformation of legal disputes. ${ }^{81}$ As described in more detail below, this framework describes three stages naming, blaming, and claiming - that constitute the progression of a legal dispute. Literature concerning models of legal protection, legal ambiguity, symbolic structures, and institutionalization of remedies also enhances the analysis.

The intuition underlying this analytical approach is that if serious crimes such as crimes against humanity and genocide are invoked in a context where mass atrocities are reportedly

\footnotetext{
${ }^{72}$ Ibid., art. 8.

${ }^{73}$ UNGA, Rome Statute of the International Criminal Court, Preamble.

${ }^{74}$ Ibid., art. 13.

${ }^{75}$ Ibid., art. 12.

${ }^{76}$ United Nations Office on Genocide Prevention and the Responsibility to Protect, "Partners," accessed November 19, 2018, http://www.un.org/en/genocideprevention/partners.html.

${ }^{77}$ United Nations, "Statement of the Special Adviser of the Secretary-General on the Prevention of Genocide on the situation in Myanmar," (press release, March 25, 2013), accessed November 19, 2018, http://www.un.org/en/ preventgenocide/adviser/pdf/Statement $\% 20$ on $\% 20$ Myanmar $\% 20-\% 2025 \% 20$ March $\% 202013$.pdf.

${ }^{78}$ Liam Cochrane, "Myanmar Could be on the Brink of Genocide, UN Expert Says," ABC Australia, September 6, 2017, accessed November 18, 2018, http://www.abc.net.au/news/2017-09-06/myanmar-on-brink-of-genocide-un-expertsay/8879858.

${ }^{79} \mathrm{Ibid}$.

80 “Unprecedented 'Level of Barbarity': UN Genocide Chief on Rohingya Visit," UN News, March 14, 2018, accessed November 16, 2018, https://news.un.org/en/audio/2018/03/1004962.

${ }^{81}$ William L.F. Felstiner, et al., “The Emergence and Transformation of Disputes: Naming, Blaming, Claiming..." Law and Society Review 15, no. 3/4 (1981), 631.
} 
taking place or threaten to occur, then a legal process providing a remedy of some kind should follow. However, responses that appear to be weak or limited in turn frustrate the expectation of a generally linear legal process that leads to some sort of resolution or adjudication. Certain factors are obstructing the process or the model of legal dispute resolution in the international context may require some adjustment. Sociology of law theories such as Felstiner et al.'s can help to delineate the components of a legal process that resolve a legal dispute or bring about the legal change required by the applicable law in a particular context. Tracing whether and to what extent international responses to the Rohingya crisis track the stages of legal dispute resolution can help to clarify the points at which the international responses, or lack thereof, diverge from the legal model. Such an analysis can elucidate what might be obstructing remedies at what stage of the legal process. This information can in turn suggest where reform efforts should focus in order to improve international legal responsiveness to mass atrocities. Such information can also help to demonstrate how international legal processes can be distinct from domestic ones, prompting further reflection on whether international responses to mass atrocities should take on characteristics that are more or less law-like, or simply different, in order to be effective.

To be sure, analyses of the relative effectiveness or ineffectiveness of international institutions in stopping or responding to mass atrocities in various cases have received significant scholarly attention. However, a substantial portion of the literature has focused on international criminal tribunals, their politics or technical aspects of international criminal legal doctrine. ${ }^{82}$ Similarly, sociological theories are largely adapted to analyzing the activities of international criminal tribunals, including the labeling of crimes such as genocide. ${ }^{83}$ These analyses are directly relevant to part of the analysis undertaken here, and they help to underscore the contribution sociology can make to international law and relations. For instance, Christensen points out how sociological studies of the International Criminal Court (ICC) can play a central role in "analyzing the social dynamics that structure its potential impact as an international institution that has been repeatedly criticized for its lack of effectiveness, efficiency and legitimacy." ${ }^{\prime 4}$ Sociological studies similarly can help to analyze the social dynamics that frustrate efforts to respond to atrocities effectively and according to international normative commitments, under the ICC's Rome Statute, the Genocide Convention, or other law or doctrine, such as the United Nations Charter or Responsibility to Protect. This paper expands on these efforts to adapt sociological theories to international law, but broadens the focus to analyze how law matters both within and beyond international tribunals as states and other actors perceive and confront their obligations to act in the face of mass atrocities. To grasp more fully why international responses have not been effective, the vision must consider the international legal system beyond international criminal justice.

Accordingly, the analysis here turns to what Galanter has called "the most important conceptual tool in analyzing legal encounters and legal change-the dispute pyramid, which traces potential pathways from 'perceived injurious experiences' to remedies, via grievances, claims, disputes, and remedial institutions like lawyers and courts." ${ }^{85}$ As Galanter asserts, "the urtext of this conceptual track" is the paper, Naming, Blaming, and Claiming by William L.F. Felstiner, Richard L. Abel, and Austin Sarat. ${ }^{86}$ Several studies have deployed this framework in domestic legal settings to identify

\footnotetext{
${ }^{82}$ Gary Bass, Stay the Hand of Vengeance: The Politics of War Crimes Tribunals (Princeton: Princeton University Press, 2000); Tim Allen, Trial Justice: The International Criminal Court and the Lord's Resistance Army (London: Zed Books, 2006); Victor Peskin, International Justice in Rwanda and the Balkans: Virtual Trials and the Struggle for State Cooperation (New York: Cambridge University Press, 2008); Adam Branch, "Uganda's Civil War and the Politics of ICC Intervention," Ethics and International Affairs 21, No. 2 (2007); Mark Kersten, Justice in Conflict: The Effects of the International Criminal Court's Interventions on Ending Wars and Building Peace (Oxford: Oxford University Press, 2016).

${ }^{83}$ Joachim Savelsberg, Representing Mass Violence: Conflicting Responses to Human Rights Violations in Darfur (Oakland: University of California Press, 2015); John Hagan and Wenona Rymond-Richmond, Darfur and the Crime of Genocide (New York: Cambridge University Press, 2008).

${ }^{84}$ Mikkel Jarle Christensen, "The Emerging Sociology of International Criminal Courts: Between Global Restructurings and Scientific Innovations," Current Sociology Review 63, no. 6 (2015), 837.

${ }^{85}$ Marc Galanter, “The Dialectic of Injury and Remedy," Loyola of Los Angeles Law Review 44 (2010), 1.

${ }^{86}$ Ibid.
} 
obstacles to effective legal responses and potential areas for reform. ${ }^{87}$ However, none appear to have adapted the dispute pyramid to the international context.

In this work, Felstiner et al. identify three transformations that occur in the emergence of a dispute. The first is "naming," or "saying to oneself that a particular experience is injurious." 88 This transformation "may be the most critical," according to the authors, as "the level and kind of disputing in a society may turn more on what is initially perceived as an injury than on any later decision." ${ }^{89}$ The second transformation, "blaming," occurs when a perceived injurious experience (PIE) is turned into a grievance. "This occurs when a person attributes an injury to the fault of another individual or social entity." wronged and believe that something might be done in response to the injury, however politically or sociologically improbable such a response might be." "91 The third transformation is "claiming," or "when someone with a grievance voices it to the person or entity believed to be responsible and asks for some remedy." ${ }^{92}$ In the context of international law, claiming is better understood in the broad sense of taking action on a PIE or grievance through various (legally justifiable) measures that states, international institutions, and individuals may use to change behavior of or punish perpetrators. This point is explored further in the subsections below.

Felstiner et al. observe, "PIEs, grievances, and disputes are subjective, unstable, reactive, complicated, and incomplete." ${ }^{193}$ Perceptions of injury, interpretations of grievance, assignation of blame, and processes of claiming may change as a result of various factors. For instance, the number of parties may not be fixed, as "new information about and redefinition of conflict" can lead a party or officials to change views about appropriate adversaries or allies. ${ }^{94}$ The relationship between the parties, whether they are linked through work, residence, or politics, or whether they have a prior history of conflict, can shape their relative status and costs of disputing. ${ }^{95}$ As the authors observe, reactivity in early stages of dispute formation is evident in how "individuals define and redefine their perceptions of experience and the nature of their grievances in response to the communications, behavior, and expectations of a range of people, including opponents, agents, authority figures, companions, and intimates. ${ }^{196}$ Characteristics such as class, education, and social networks can also influence the development of disputes. ${ }^{97}$ Additional factors and actors play a role or may evolve in the emergence and transformation of disputes, such as the identity of the parties and the scope of conflict, or the extent of relevant discourse about grievances and claims. ${ }^{98}$ Other factors include choice of mechanisms, objectives sought, reference groups (audiences or sponsors), and representatives and officials (such as lawyers, social workers, government officials, and bureaucrats). ${ }^{99}$ The following subsections explore how these concepts and factors play out in the context of the Rohingya crisis and international law and responses.

\footnotetext{
${ }^{87}$ Michael Orsini, “The Politics Of Naming, Blaming, and Claiming: HIV, Hepatitis C, and the Emergence of Blood Activism in Canada," Canadian Journal of Political Science 35 (2002), 475; Carolyn Weithoff, "Naming, Blaming, and Claiming in Public Disputes: The 1998 Maine Referendum on Civil Rights Protection for Gay Men and Lesbians," Journal of Homosexuality 44 (2003), 61.

${ }^{88}$ Felstiner, et al, 635 .

${ }^{89}$ Ibid.

${ }^{90}$ Ibid.

${ }^{91}$ Ibid.

${ }^{92}$ Ibid.

${ }^{93}$ Ibid., 637.

${ }^{94}$ Ibid., 639.

${ }^{95}$ Ibid., 640.

${ }^{96}$ Ibid., 638.

${ }^{97}$ Ibid., 632-633.

${ }^{98}$ Ibid., 641.

${ }^{99}$ Ibid., 642-646.
} 
Naming and Blaming: Different Legal Terms, Different Weights of Responsibility

Many of the challenges of naming, blaming, and claiming in the context of the Rohingya stem from the relevant laws' ambiguous terms and modes of application. As Felstiner et al. mention, how the injury is perceived - or which word or words are used to identify it - "may be the most critical" to how the dispute takes shape. ${ }^{100}$ As discussed, most experts would concede that a reasonable prima facie case of crimes against humanity and at least risk of genocide can be established, if not genocide itself. The ambiguity or challenge in the case of naming crimes against humanity and especially genocide concern how much certainty of the crime's likelihood or actual existence is required in order to apply the name and justify a response. An additional question is what kinds of responses are adequate to meet international legal obligations if the crimes likely or actually amount to crimes against humanity or genocide.

Relatedly, another question is whether the distinction between crimes against humanity and genocide even really matters. Two understandings of crimes against humanity and genocide currently seem to coexist. The first, arguably progressive understanding is that since the UN General Assembly embraced the Responsibility to Protect (R2P) in 2005, the obligations to act on the part of states and the international community are the same whether the crimes concerned are war crimes, crimes against humanity, ethnic cleansing, or genocide. ${ }^{101}$ This reflects the evolved view on the part of the international community that all of these crimes constitute "unimaginable atrocities that deeply shock the conscience of humanity." 102 As U.S. Secretary of State Colin Powell said of the violence in Darfur, Sudan in 2005, whether or not the crime of genocide applied, U.S. policy toward Sudan would remain the same in terms of pressuring the Khartoum government to stop abuses and providing humanitarian relief; "applying the 'genocide' label would not require anything more from the United States." 103 The second, traditional understanding is that notwithstanding R2P, the notion of genocide continues to carry special meaning because of its intent requirement; the specific intent to destroy an ethnic or religious group, "as such," and thus sits at the top of a hierarchy of grave crimes. ${ }^{104}$ As noted, this specific intent requirement imposes a high burden of proof, demanding that evidence be "fully conclusive." ${ }^{105}$ This strict standard thus "renders genocide determinations unavoidably contestable."106

In addition to the contestability of genocide determinations, R2P is at best an unsettled doctrine. ${ }^{107}$ As Chesterman points out, by the time the UN General Assembly endorsed R2P in 2005, "its normative content had been emasculated to the point where it essentially provided that the Security Council could authorize, on a case-by-case basis, things that it had been authorizing for more than a decade." ${ }^{108}$ It nonetheless had normative significance, in that while "the true significance of $[\mathrm{R} 2 \mathrm{P}]$ is not in creating new rights or obligations to do 'the right thing'; rather, it is in making it harder to do the wrong thing or nothing at all." 109 The terms regarding how the international community can fulfill its commitment to protect populations are open-ended. As provided in the Outcome Document, the international community, "through the United Nations," is to "use appropriate diplomatic, humanitarian, and other peaceful means." It is "prepared to take collective action... on a case-by-case basis and in cooperation with relevant regional organizations

\footnotetext{
${ }^{100}$ Ibid., 635.

${ }^{101}$ UNGA, 2005 World Summit Outcome, para. 138.

${ }^{102}$ UNGA, Rome Statute of the International Criminal Court, Preamble, para. 2.

${ }^{103}$ Scott Straus, "Darfur and the Genocide Debate," Foreign Affairs 84, no. 1 (January-February 2005), 130.

${ }^{104}$ Payam Akhavan, Reducing Genocide to Law: Definition, Meaning, and the Ultimate Crime (Cambridge: Cambridge University Press, 2012).

${ }^{105}$ Bosnia and Herzegovina v. Serbia and Montenegro, Case Concerning Application of the Convention on the Prevention and Punishment of the Crime of Genocide, Judgment, I.C.J. Reports 2007, para. 209.

${ }^{106}$ Southwick, Confronting Genocide in Myanmar.

${ }^{107}$ Simon Chesterman, "'Leading from Behind' The Responsibility to Protect, the Obama Doctrine, and the Humanitarian Intervention after Libya," Ethics E International Affairs 25, no. 3 (2011), 282.

${ }^{108}$ Ibid., 280.

${ }^{109}$ Ibid., 282.
} 
as appropriate." 110 In comparison, the 1948 Genocide Convention is a binding treaty with 146 States Parties. It is clearer than R2P with respect to obligations to act and more concrete steps to take, such as extraditing and trying alleged perpetrators in a competent tribunal, punishing offenders, and submitting disputes concerning the interpretation and application of the Convention to the International Court of Justice (ICJ). ${ }^{111}$

The sense of hierarchy between the two terms of crimes against humanity and genocide feeds reluctance to act unless the term of genocide is applied. The genocide label heightens the scrutiny and thereby the pressure applied to parties obligated to act. Presumably Secretary Powell implicitly sensed this distinction when he, notwithstanding his remarks about the equivalence of crimes against humanity and genocide, eventually commissioned an inquiry into whether the events in Darfur constituted genocide. ${ }^{112}$ If genocide is therefore perceived to be a more serious crime, triggering greater expectation of action, states and other institutions may seek to avoid that label, depending on the interests they may have at stake. As a result, the crime is not named and crimes against humanity in turn inspire less urgency. The dispute thus has limited scope for transformation.

In some respects, this scenario appears to be playing out in the case of the Rohingya. For a government or the UN to allege or name genocide or the risk of genocide would raise some expectation of some kind of punitive or coercive action against the Myanmar government. Such efforts could compromise the international community's effort to incentivize further national reforms in Myanmar and expand business and other opportunities for all through reduced sanctions and increased investment and engagement. Having waited a half-century for the country to move out of isolation and embrace democracy and human rights, international actors may resist the idea of appearing to turn back the clock. Cognitive dissonance is also generated when human rights authority figures such as Nobel Laureate Aung San Suu Kyi decline to discuss persecution of the Rohingya, presumably out of concern for her own capacity to assert political influence towards other ostensibly good ends within the country. Moreover, the question of naming has been taken to an extreme with government officials requesting that the term "Rohingya" not even be used. ${ }^{113}$ This signals to the Rohingya and the international community that they too risk backlash if they discuss the plight of the community, let alone label it genocide. Only since late 2017, when the scale of violence and displacement had reached a mysterious threshold of egregiousness, could officials no longer avoid the term genocide.

Another dynamic that complicates the naming process in the Rohingya case is the diffusion of authority in naming the crime so as to compel or credibly pressure action. Perhaps the most authoritative source absent adjudication by the ICC or ICJ would be the United Nations. Up until late 2017, UN officials had described the plight of the Rohingya as a "profound crisis," which "has the potential to undermine the entire reform process in Myanmar." ${ }^{114}$ In September 2017, a UN official characterized the Rohingya crisis as ethnic cleansing, but none until December 2017 officially linked the situation with genocide. The Special Representative on Genocide Prevention has on a couple of occasions identified the risk of genocide, but averred that only a court could make a genocide determination. The fact-finding mission established by the Human Rights Council assuredly found in August 2018 that genocidal intent on the part of Myanmar authorities could reasonably be inferred based on the circumstances of the Rohingya case. Yet it went on to defer to a judicial process to investigate and prosecute senior officials "so that a competent court can

${ }^{110}$ UNGA, 2005 World Summit Outcome, para. 139.

${ }^{111}$ United Nations, Convention on the Prevention and Punishment of the Crime of Genocide, articles 4-9.

112 U.S. Secretary of State Colin L. Powell, "The Crisis in Darfur," (testimony, Washington, DC, September 9, 2004), Senate Foreign Relations Committee, accessed November 19, 2018, https://2001-2009.state.gov/secretary/former/powell/ remarks/36042.htm.

113 Todd Pitman and Julie Pace, “Obama Says 'Rohingya,' Displeasing Myanmar Hosts," ABCNews, November 14, 2014, accessed November 19, 2018, http://abcnews.go.com/International/wireStory/group-obama-rohingya-myanmarvisit-26904145.

114 Tomás Ojéa Quintana, Report of the Special Rapporteur on the Situation of Human Rights in Myanmar, United Nations Human Rights Council, March 6, 2013 (UN Doc. A/HRC/22/58), para. 46, accessed November 19, 2018, http://www. ohchr.org/Documents/HRBodies/HRCouncil/RegularSession/Session22/A.HRC.22.58 AUV.pdf. 
determine their liability for genocide in relation to the situation in Rakhine State."115 Similarly, back in 2015, while Yale Law School's human rights clinic found "strong evidence that the abuses against the Rohingya satisfy the [] elements of genocide," it went on to call upon the United Nations to establish an independent commission of inquiry on the human rights situation in Rakhine State and whether the crime of genocide is applicable. ${ }^{116}$ These statements leave the impression that courts or other authoritative bodies largely make definitive genocide determinations, typically reached, if at all, years after the events have taken place. In the mean time, this deferral of authority on whether or not a situation amounts to or could amount to genocide can confuse understanding of appropriate responses, be they preventive or protective after the fact. Somewhat distinctively and as noted above, the November 2017 report by Fortify Rights and the Simon Skojt Center at the U.S. Holocaust Memorial Museum was clear that the international community "should not wait for a formal legal determination of genocide to take immediate action." ${ }^{117}$

In line with that latter approach, in terms of obtaining some sort of action, states themselves either need to broaden their openness to considering the application of genocide, at least acting in the interest of preventing or reducing the risk of genocide, or accept a responsibility to act as robustly if the crimes are deemed best described as crimes against humanity.

In addition to deferring to courts or official commissions to make definitive determinations, diffusion of authority in naming also manifests in terms of the various actors who precede official institutions in labeling atrocity crimes. From 2011 to 2018, scholars, activists, and organizations have increasingly brought up the term of genocide, sometimes in terms of describing a risk of genocide, though some could reasonably argue that a "slow-burning" genocide has been under way for years. ${ }^{118}$ It therefore seems in this situation that the process of naming crimes is an uneven consensus-building one that originates from civil society, academia, and the media and eventually penetrates (or not) the legal departments of official institutions. This view is consistent with Prunier's characterization of atrocities in Darfur, Sudan as "the ambiguous genocide," due to the diverse positions on the question taken by the United States, the United Nations, the European Union, and human rights organizations. ${ }^{119}$ These indefinite dynamics concerning which terms to use to name injuries, and who has the authority to apply names, are consistent with Felstiner et al.'s observation about the instability, complexity, and incompleteness of disputes. However, in the international system, this instability is magnified, as no central body is consistently invoked to pronounce in a timely way on whether a crime is appropriately labeled one thing or another. Additionally, preventive norms allowing or mandating action in the absence of legal certainty remain nebulous. Accordingly, naming and blaming become more difficult.

\section{Claiming: Constrained Models of Legal Protection}

Problems of ambiguity, vagueness, and diffusion of authority and responsibility also apply in the processes of claiming rights and protection for the Rohingya. As noted above, "claiming" in Felstiner et al.'s framework is "when someone with a grievance voices it to the person or entity believed to be responsible and asks for some remedy." 120 In the context of international law, particularly atrocity law, claiming is better understood in the broad sense of taking action on a PIE or grievance through legally justifiable measures that states, international institutions, and individuals may use to change behavior or punish perpetrators. The applicable legal authorities of R2P, the Genocide Convention, and the ICC's Rome Statute assign the roles of naming, blaming, and claiming to additional actors beyond the victims. These include states themselves, regional organizations such as the Association of Southeast Asian Nations (ASEAN), the UN Security Council, UN special mechanisms such as Special Rapporteurs, and the ICC Prosecutor, among others. Civil society

\footnotetext{
${ }^{115}$ United Nations Human Rights Council, Report of the international fact-finding mission on Myanmar, para. 87.

${ }^{116}$ Allard K. Lowenstein International Human Rights Clinic, Persecution of the Rohingya Muslims.

${ }^{117}$ Ibid.

${ }^{118}$ Zarni and Cowley, The Slow-Burning Genocide of Myanmar's Rohingya.

${ }^{119}$ John Hagan and Wenona Rymond-Richmond, Darfur and the Crime of Genocide (New York: Cambridge University Press, 2008), 31, 34

${ }^{120}$ Felstiner, et al, 635.
} 
groups also take on these roles on behalf of victims, implicitly acknowledging that victims under conditions comparable to crimes against humanity or genocide may be so suppressed or threatened that advocacy on their own behalf is severely constrained. This variety of actors, and the range of measures they might consider to assert claims or seek enforcement, would seem to amplify but also complicate the possibility of dispute emergence and transformation (and consequent resolution) for the Rohingya.

Bumiller's notion of the "model of legal protection," Edelman's concepts of "legal ambiguity and symbolic structures," and Miller and Sarat's observations on the institutionalization of remedies are helpful in elucidating some of the claiming challenges. They also help to suggest differences in the operation of international versus domestic law.

Bumiller observes that discrimination laws and policies - of which genocide and crimes against humanity such as persecution can be said to constitute a version - are based on a model of legal protection, "which assumes that those who have suffered harms will recognize their injuries and invoke the protective measures of the law." ${ }^{21}$ She adds that, "these laws tacitly assume that such behavior is reasonably unproblematic." ${ }^{122}$ However, in Bumiller's study of the effectiveness of antidiscrimination laws in the United States, she found that the success of these laws were frustrated by what she termed an "ethic of survival," whereby alleged victims did not pursue claims for various reasons related to self-preservation and avoidance of potentially exacerbated problems. For instance, they feared retaliation from employers in the form of job loss or increased hostility or humiliation. They were deterred by the financial and emotional costs of disputing, among other factors. ${ }^{123}$

$\mathrm{R} 2 \mathrm{P}$, the Genocide Convention, and the Rome Statute attach to the crimes they cover a sense of egregiousness and outrage, suggesting that such crimes are and will be easily identified and acted upon, tacitly implying, per Bumiller, that the appropriate response is unproblematic. Yet as noted, unlike the domestic discrimination laws in Bumiller's study, these laws do not solely or explicitly place the burden of recognition of injury and initiation of action (naming and claiming) on the victims. The burden of naming and claiming is shared with the international community, states, international institutions, and implicitly civil society. Under these legal frameworks, the states within which the crimes are occurring have the first responsibility to protect. However, when the states are themselves implicated in the crimes, responsibility for action diffuses within the international community, leading to a situation where others wait for others to act, displaying a kind of "ethic of survival" whereby states and institutions such as the UN or ICC do not act because they individually do not wish to risk compromising whatever interests or perception of credibility they may have in the situation. These other interests may include other humanitarian concerns in the country, an emotional or political investment in Myanmar's eventual democratic transition, business or regional security interests, fear of some sort of backlash that could damage credibility or operations, or other global crises demanding resources and attention.

In avoiding the process of claiming, international actors draw upon legal ambiguity to erect institutions, or what Edelman calls "symbolic structures," that lack inherent enforcement capacity. As Edelman explains

The opportunity for organizations to mediate law is variable. Laws that contain vague or controversial language, laws that regulate organizational procedures more than the substantive results of those procedures, and laws that provide weak enforcement mechanisms leave more room for organizational mediation than laws that are more specific, substantive, and backed by strong enforcement. ${ }^{124}$

\footnotetext{
${ }^{121}$ Kristin Bumiller, "Victims in the Shadow of the Law: A Critique of the Model of Legal Protection," Signs 12, no. 3 (Spring 1987), 422. 
She goes on to state that laws with "broad and ambiguous principles" can afford organizations "wide latitude to construct the meaning of compliance."125

In the case of the Rohingya, various institutions exist whose mandates would cover the abuses the minority faces, but various factors mediate the effectiveness of enforcement. While the UN Security Council has held briefings and even traveled to the region in April 2018, ${ }^{126}$ Russia and China are widely expected to veto sanctions or other coercive steps against Myanmar that other Security Council members might seek to apply under the UN Charter. ${ }^{127}$

The UN Special Adviser on the Prevention of Genocide has a mandate to provide early warning and build international capacity to respond to genocide. However, his office has issued few statements on the Rohingya and whether any other diplomatic steps up until this latest round of violence have been taken to promote action is unclear. His capacity to promote effective responses depends in part on the political will of states to engage, and so limited action may therefore reflect a lack of political will or the absence of "normative pressure from [his] environment to elaborate formal structures to create visible symbols of [his] attention to law." 128 Somewhat insulated from external scrutiny, this office is difficult to evaluate. As Edelman notes, "most organizations' construction of compliance is never examined in court. Thus organizations' collective response to law becomes the de facto construction of compliance; it is shaped only at the margins by formal legal institutions."129

Special Rapporteurs for Human Rights have served a role in documenting abuses and legitimizing efforts to name crimes, at least as crimes against humanity, and pursue claims. But these roles too are shaped by the initiative or lack thereof of their occupants. In 2014, Special Rapporteur Yanghee Lee took the opportunity to counter efforts to suppress the term, "Rohingya," stating that

I was repeatedly told not to use the term 'Rohingya' as this was not recognized by the Government. Yet, as a human rights independent expert, I am guided by international human rights law ... the rights of minorities to self-identify on the basis of their national, ethnic, religious, and linguistic characteristics is related to the obligations of States to ensure nondiscrimination against individuals and groups, which is a central principle of international human rights law. ${ }^{130}$

In March 2018, before the fact-finding mission had released its report, she stated to the UN Human Rights Council, "I am becoming more convinced that the crimes committed following 9 October 2016 and 25 August 2017 bear the hallmarks of genocide, and call in the strongest terms for accountability." 131 Because the Rapporteur is directly engaged in Myanmar, perhaps she feels greater normative pressure to take steps demonstrating compliance with the mandate of her position. These statements also reflect the potential of rights to serve as a "cultural or symbolic

\footnotetext{
${ }^{125}$ Ibid.

${ }^{126}$ United Nations, Myanmar's Refugee Problem Among World's Worst Humanitarian, Human Rights Crises, Secretary-General Says in Briefing to Security Council, Security Council 8333 rd Meeting Coverage, August 28, 2018 (UN Doc. S/13469); "Security Council Urges Conditions that Allow Safe Return of Rohingya Refugees," UN News, May 1, 2018, accessed November 20, 2018, https://news.un.org/en/story/2018/05/1008692.

${ }^{127}$ Michelle Nichols, “Nine U.N. Security Council Members Ask to Discuss Myanmar Inquiry,” Reuters, October 16, 2018, accessed November 20, 2018, https://www.reuters.com/article/us-myanmar-rohingya-un/nine-un-security-councilmembers-ask-to-discuss-myanmar-inquiry-idUSKCN1MR07W.

${ }^{128}$ Ibid., 1531.

${ }^{129}$ Ibid., 1568.

130 "I Was Repeatedly Told Not to Use the Term 'Rohingya' as This Was Not Recognized by the Government: Yang Hee Lee, UN Special Rapporteur," Kaladan Press Network, August 2, 2014, accessed November 19, 2018, http://www. kaladanpress.org/index.php/news/372-news2014/august-2014/4614-i-was-repeatedly-told-not-to-use-the-term\%E2\%80\%98rohingya\%E2\%80\%99-as-this-was-not-recognized-by-the-government-ms-yang-hee-lee,-un-specialrapporteur.html.

${ }^{131}$ Megan Duzor, "UN Rights Official: Events in Rakhine State Bear Hallmarks of Genocide," VOA News, March 12, 2018, accessed November 16, 2018, https://www.voanews.com/a/events-in-rakhine-state-bear-hallmarks-ofgenocide/4295342.html.
} 
resource" in promoting social change. ${ }^{132}$ As Albiston points out, "mobilizing rights, even in informal contexts, can ... delegitimize conduct previously accepted as natural or normal."133

Another institution with a relevant mandate is the ASEAN Intergovernmental Commission on Human Rights (AICHR). While one of its purposes is to promote and protect human rights in the ASEAN region, realization of rights is mediated and constrained by the fact that it has no formal complaint mechanism and by principles of non-confrontation and consensus among its members. ${ }^{134}$ Individual government responses are mediated by the complexity of formulating and implementing foreign policy. In the U.S. Government, for instance, the process of pursuing claims for the Rohingya involves coordination among multiple agencies within the U.S. State Department, National Security Council, and U.S. Congress.

With respect to international tribunals, Becker finds that while the International Court of Justice would have jurisdiction over a dispute regarding Myanmar's compliance with the Genocide Convention, persuading a non-injured state to bring such a case would be politically difficult. ${ }^{135}$ The International Criminal Court (ICC), while empowered to bring justice to victims, remains constrained. The ICC and other international tribunals depend on the cooperation of states, including cooperation from states under investigation for criminal behavior. ${ }^{136}$ As Peskin has documented, despite wide ratification of the Rome Statute, lack of political support hampers state cooperation with the ICC. ${ }^{137}$ Accordingly, the distinction that Alter et al. draw between the legal competence and actual, de facto authority of international institutions plays out with respect to international legal responses more broadly. ${ }^{138}$

Together, the obstacles to naming, blaming, and claiming in the context of the Rohingya crisis suggest limited institutionalization of remedies. As Miller and Sarat have observed, "Higher levels of institutionalization ... would be associated with higher rates of grievance perception and claiming ... and higher rates of success in recovery for meritorious claims." ${ }^{139}$ Institutionalization of remedies is denoted by "well-known, regularized, readily available mechanisms, techniques, or procedures for dealing with a problem." ${ }^{140}$ In the case of atrocity prevention and cessation, as in the case of the Rohingya, remedies are not regularized or readily apparent, but are highly dependent on the balance of and interaction of interests among states and the international community. This makes for ad hoc, case-by-case, and overly slow approaches to allegations of crimes against humanity and genocide, addressed by institutions with limited enforcement capacity.

\section{Conclusion}

The challenges in naming, blaming, and claiming rights and protection for the Rohingya largely arise from the ambiguity in relevant laws concerning mass atrocity, the diffusion of authority and responsibility that occurs in those laws' application, and the relative lack of enforcement capacity of institutions, such as the UN, ICJ, and ICC, squarely tasked with protecting against or prosecuting grave crimes such as crimes against humanity and genocide. The international system is a clear example of Miller and Sarat's point that, "It is easier, on the whole, for societies to declare rights than to provide remedies; indeed, the development of remedies almost inevitably

\footnotetext{
${ }^{132}$ Catherine R. Albiston, "Bargaining in the Shadow of Social Institutions: Competing Discourses and Social Change in Workplace Mobilization of Civil Rights," Law and Society Review 39, no. 1 (2005), 14.

${ }^{133}$ Ibid.

${ }^{134}$ ASEAN Intergovernmental Commission on Human Rights, Terms of Reference (Jakarta: ASEAN Secretariat, 2009), articles 1,4 .

${ }^{135}$ Michael A. Becker, “Is There a Role for the International Court of Justice?” EJIL: Talk!, November 14, 2018, accessed November 18, 2018, https://www.ejiltalk.org/the-situation-of-the-rohingya-is-there-a-role-for-the-international-courtof-justice/.

${ }^{136}$ Under Article 12, Myanmar may accept the jurisdiction of the court on an ad hoc basis, an unlikely possibility.

${ }^{137}$ Peskin, International Justice in Rwanda and the Balkans, 251.

${ }^{138}$ Karen J. Alter, et al, "How Contexts Shape the Authority of International Courts," Law and Contemporary Problems 79 (2016), 1.

${ }^{139}$ Richard E. Miller and Austin Sarat, "Grievances, Claims, and Disputes: Assessing the Adversary Culture," Law and Society Review 15, no. 3/4 (1981), 564.

${ }^{140}$ Ibid., 563.
} 
lags behind the recognition of rights."141 Seventy years since the adoption of the UN Genocide Convention, however, seems like an unusually long lag for effective remedies to develop. Yet the situation of the Rohingya illustrates some of the unique features of and constraints on international law. The processes of naming and claiming rights is more diffuse, and thus generally renders the emergence and transformation of disputes on behalf of victims more unstable, complex, and arduous than in domestic settings. Courts such as the ICC and ICJ may or may not play a role, and non-judicial responses, mediated by competing interests of actors obligated to act, arguably operate less in the shadow of courts than they do in domestic legal settings. Legal concepts and structures become more dependent upon, embedded in, and transfigured by political and social dynamics, amidst negotiations among and between states and private actors, at international and local levels. International human rights law is therefore less legal in nature and more social and political.

Felstiner et al. aver that "a healthy social order is one that minimizes barriers inhibiting the emergence of grievances and disputes and preventing their translation into claims for redress." 142 By this measure, the barriers to remedies the Rohingya have faced for over thirty years would signal that the international human rights order is unhealthy. It remains for further research to identify the specific reforms needed to remedy these weaknesses, but the dispute pyramid helps to identify areas for consideration, specifically the development of streamlined processes for naming crimes and clarification of roles and responsibilities for states and international institutions to act preventively and decisively in the absence of legal certainty. Such an approach would in a sense flip the dispute pyramid to allow for claiming to precede definitive naming, moving toward a model of crime prevention rather than legal dispute transformation. As the UN has stated, "prevention is the first imperative of justice."143 Prevention is explicitly the point of "Never Again." 144 More broadly, the application of Felstiner et al.'s legal lens to the Rohingya crisis helps to uncover a paradox about law in the international context, where law is both peripheral and central. Law is peripheral because social and political dynamics obstruct and overwhelm its operation. At the same time, law is central as it enshrines a moral, animating value that compels imagining more effective institutions and enforcement procedures, whether they are increasingly law-like or not.

\section{Acknowledgements}

I would like to thank the Centre for Asian Legal Studies at the National University of Singapore's Faculty of Law for its support of previous research into minority rights in Myanmar. I would also like to thank students and faculty at George Mason University's School for Conflict Analysis and Resolution, as well as two anonymous reviewers, who provided valuable feedback on an earlier version of this paper.

\section{Bibliography}

Akhavan, Payam. Reducing Genocide to Law: Definition, Meaning, and the Ultimate Crime. (Cambridge: Cambridge University Press, 2012). https://doi.org/10.1017/CBO9781139028943

Al Hussein, Zeid Ra'ad. "Darker and More Dangerous: High Commissioner Updates the Human Rights Council on Human Rights Issues in 40 Countries." Opening Statement, Geneva, September 11, 2017. United Nations Human Rights Council. Accessed November 15, 2018. http://www.ohchr.org/EN/NewsEvents/Pages/DisplayNews. aspx?NewsID=22041\&LangID $=\mathrm{E}$.

Albiston, Catherine R. "Bargaining in the Shadow of Social Institutions: Competing Discourses and Social Change in Workplace Mobilization of Civil Rights." Law and Society Review 39, no. 1 (2005), 11-50. https://doi.org/10.1111/j.0023-9216.2005.00076.x

\footnotetext{
${ }^{141}$ Ibid., 564.

${ }^{142}$ Felstiner et al., 654.

${ }^{143}$ United Nations, The Rule of Law and Transitional Justice in Conflict and Post-Conflict Societies, Report of the SecretaryGeneral, August 23, 2004 (UN Doc. S/2004/616), para. 4.

${ }^{144}$ Emily Burack, “'Never Again: From a Holocaust Phrase to a Universal Phrase," Jerusalem Post, March 10, 2018, accessed November 18, 2018, https://www.jpost.com/Diaspora/Never-Again-From-a-Holocaust-phrase-to-a-universalphrase-544666.
} 
Allard K. Lowenstein International Human Rights Clinic. Persecution of the Rohingya Muslims: Is Genocide Occurring in Myanmar's Rakhine State? A Legal Analysis. New Haven: Yale Law School, October 2015. Accessed November 18, 2018. http://www.fortifyrights.org/ downloads/Yale Persecution of the Rohingya October 2015.pdf.

Allen, Tim. Trial Justice: The International Criminal Court and the Lord's Resistance Army. London: Zed Books, 2006.

Alter, Karen J., Laurence R. Helfer, and Mikael Rask Madsen. “How Contexts Shape the Authority of International Courts." Law and Contemporary Problems 79, no. 1 (2016), 1-36.

ASEAN Intergovernmental Commission on Human Rights. Terms of Reference. Jakarta: ASEAN Secretariat, 2009.

"Attacks on Myanmar's Rohingya 'Genocide' - Macron." RTE, September 21, 2017. Accessed December 19, 2017. https://www.rte.ie/news/2017/0921/906399-rohingya/.

Bass, Gary. Stay the Hand of Vengeance: The Politics of War Crimes Tribunals. Princeton: Princeton University Press, 2000.

Bearak, Max. "Bangladesh Is Now Home to Almost 1 Million Rohingya Refugees." Washington Post, October 25, 2017. Accessed November 15, 2018. https://www.washingtonpost.com/news/ worldviews/wp/2017/10/25/bangladesh-is-now-home-to-almost-1-million-rohingyarefugees/?utm term=.db5f3fef4e8f.

Becker, Michael A. "Is There a Role for the International Court of Justice?" EJIL: Talk! November 14, 2018. Accessed November 18, 2018. https://www.ejiltalk.org/the-situation-of-the-rohingyais-there-a-role-for-the-international-court-of-justice/.

Branch, Adam. "Uganda's Civil War and the Politics of ICC Intervention." Ethics and International Affairs 21, no. 2 (2007), 179-198. https://doi.org/10.1111/j.1747-7093.2007.00069.x

Bumiller, Kristin. "Victims in the Shadow of the Law: A Critique of the Model of Legal Protection." Signs 12, no. 3 (Spring 1987), 421-439. https://doi.org/10.1086/494337

Burack, Emily. "'Never Again: From a Holocaust Phrase to a Universal Phrase." Jerusalem Post, March 10, 2018. Accessed November 18, 2018. https://www.jpost.com/Diaspora/NeverAgain-From-a-Holocaust-phrase-to-a-universal-phrase-544666.

Chazan, Yigal. "Foreign Investors Jittery Amid Myanmar's Rohingya Crisis." The Diplomat, October 21, 2017. Accessed December 18, 2017. https://thediplomat.com/2017/10/foreign-investorsjittery-amid-myanmars-rohingya-crisis/.

Christensen, Mikkel Jarle. "The Emerging Sociology of International Criminal Courts: Between Global Restructurings and Scientific Innovations." Current Sociology Review 63, no. 6 (2015), 825-849. https://doi.org/10.1177/0011392115588963

Cochrane, Liam. "Myanmar Could Be on the Brink of Genocide, UN Expert Says." ABC Australia, September 6, 2017. Accessed November 19, 2018. http://www.abc.net.au/news/2017-09-06/ myanmar-on-brink-of-genocide-un-expert-say/8879858.

Congress of the United States, Letter from Various U.S. Members of Congress to U.S. Secretary of State John Kerry. July 31, 2014. Accessed December 18, 2017. http://www.burmapartnership.org/ wp-content/uploads/2014/08/Letter-from-Members-of-the-US-Congress-to-Secretary-ofState-John-Kerry.pdf.

Cronin-Furman, Kate. “Calling a Genocide a Genocide." Slate, October 31, 2017. Accessed November 18, 2018. http://www.slate.com/articles/news and politics/foreigners/2017/10/the word genocide is overused but it applies to what s happening to the.html.

Cumming-Bruce, Nick. "Myanmar's Rohingya Actions May be Genocide, U.N. Official Says." New York Times, December 5, 2017. Accessed November 19, 2018. https://www.nytimes. com/2017/12/05/world/asia/myanmar-rohingya-genocide-un.html? $\mathrm{r}=0$.

Duzor, Megan. "UN Rights Official: Events in Rakhine State Bear Hallmarks of Genocide."

VOA News, March 12, 2018. Accessed November 16, 2018. https://www.voanews.com/a/events-inrakhine-state-bear-hallmarks-of-genocide/4295342.html.

Edelman, Lauren B. "Legal Ambiguity and Symbolic Structures: Organizational Mediation of Civil Rights Law." American Journal of Sociology 97, no. 6 (May 1992), 1531-1576. https://doi. org/10.1086/229939 
"EU to Scale Back Relations with Myanmar's Military." Financial Times, October 16, 2017. Accessed November 18, 2018. https://www.ft.com/content/cf0b94f6-b25d-11e7-a398-73d59db9e399.

"Expert Warns of Rohingya Genocide." Al Jazeera, March 3, 2013. Accessed November 18, 2018. http://www.aljazeera.com/pressoffice/2013/03/20133210535530465.html.

Felstiner, William L.F., Richard L. Abel, and Austin Sarat. "The Emergence and Transformation of Disputes: Naming, Blaming, Claiming..." Law and Society Review 15, no. 3/4 (1981), 631-654. https://doi.org/10.2307/3053505

Ferrie, Jared. "US Says Myanmar Should Draft New Plan to Give Rohingya Citizenship." Reuters, November 13, 2014. Accessed November 15, 2018. https://www.reuters.com/article/ us-myanmar-rohingya/u-s-says-myanmar-should-draft-new-plan-to-give-rohingyacitizenship-idUSKCNOIXOLE20141113.

Finegan, Conor. "When Europe, Canada Slapped New Sanctions on Myanmar over Rohingya Treatment, Where Was US?" ABC News, July 8, 2018. Accessed November 16, 2018. https://abcnews.go.com/International/europe-canada-slapped-sanctions-myanmarrohingya-treatment-us/story?id=56441577.

Fortify Rights. They Gave Them Long Swords: Preparations for Genocide and Crimes against Humanity Against Rohingya Muslims in Rakhine State, Myanmar. July 2018. Accessed November 16, 2018. https://www.fortifyrights.org/downloads/Fortify Rights Long Swords July 2018.pdf.

Fortify Rights and Simon Skjodt Center for the Prevention of Genocide, United States Holocaust Memorial Museum. "They Tried to Kill Us All": Atrocity Crimes against Rohingya Muslims in Rakhine State, Myanmar. November 2017. Accessed November 16, 2018. https://www. ushmm.org/m/pdfs/201711-atrocity-crimes-rohingya-muslims.pdf.

Fuller, Thomas. "Extremism Rises Among Myanmar Buddhists." New York Times, June 20, 2013. Accessed November 15, 2018. http://www.nytimes.com/2013/06/21/world/asia/extremismrises-among-myanmar-buddhists-wary-of-muslim-minority.html.

Galanter, Marc. "The Dialectic of Injury and Remedy." Loyola of Los Angeles Law Review 44 (2010), $1-10$.

Garcia, Sean and Camille Olson. Rohingya: Burma's Forgotten Minority. Refugees International. December 18, 2008. Accessed November 15, 2018. http://www.refugeesinternational.org/ policy/field-report/rohingya-burma $\% \mathrm{E} 2 \% 80 \% 99$ s-forgotten-minority.

Gettleman, Jeffrey. "Rohingya Recount Atrocities: They Threw My Baby Into a Fire." New York Times, October 11, 2017. Accessed November 15, 2018. https://www.nytimes.com/2017/10/11/ world/asia/rohingya-myanmar-atrocities.html? $\mathrm{r}=0$.

Green, Penny, Thomas MacManus, and Alicia de la Cour Venning. Countdown to Annilation: Genocide in Myanmar. London: Queen Mary University of London, School of Law, International State Crime Initative, 2015. Accessed November 18, 2018. http://statecrime.org/data/2015/10/ ISCI-Rohingya-Report-PUBLISHED-VERSION.pdf.

Hagan, John and Wenona Rymond-Richmond. Darfur and the Crime of Genocide. New York: Cambridge University Press, 2009.

Heavey, Susan and Arshad Muhammad. "U.S. Sanctions Myanmar General Accused of Carrying Out Ethnic Cleansing Campaign Against Rohingya." Time, December 22, 2017. Accessed November 16, 2018. http://time.com/5077015/us-sanctions-rights-abusers-myanmargeneral/.

Human Rights Watch. "Burma: Satellite Imagery Shows Mass Destruction." September 19, 2017. Accessed November 15, 2018. https://www.hrw.org/news/2017/09/19/burma-satelliteimagery-shows-mass-destruction.

----------. "Burma: Government Plan Would Segregate Rohingya." October 3, 2014. Accessed November 15, 2018. http://www.hrw.org/news/2014/10/03/burma-government-planwould-segregate-rohingya.

---------. All You Can Do is Pray: Crimes against Humanity and Ethnic Cleansing of Rohingya Muslims in Burma's Arakan State. HRW, 2013.

"I Was Repeatedly Told Not to Use the Term 'Rohingya' as This Was Not Recognized by the Government: Yang Hee Lee, UN Special Rapporteur." Kaladan Press Network, August 2, 2014. Accessed December 19, 2017. http://www.kaladanpress.org/index.php/ 
news/372-news2014/august-2014/4614-i-was-repeatedly-told-not-to-use-the-term\%E2\%80\%98rohingya \%E2\%80\%99-as-this-was-not-recognized-by-the-government-msyang-hee-lee,-un-special-rapporteur.html.

International Criminal Court, Office of the Prosecutor. "Statement of ICC Prosecutor, Mrs. Fatou Bensouda, on opening a Preliminary Examination concerning the alleged deportation of the Rohingya people from Myanmar to Bangladesh." Statement, The Hague, September 18, 2018. Accessed November 16, 2018. https://www.icc-cpi.int/Pages/item.aspx?name=180918otp-stat-Rohingya.

International Organization of Migration. "IOM Bangladesh: Rohingya Humanitarian Crisis Response External Report." October 19-25, 2018. Accessed November 18, 2018. https://www.iom.int/sites/default/files/situation reports/file/bangladesh sr 20181019-25.pdf.

IRIN. "Analysis: In Search of a Regional Rohingya Solution." July 26, 2013. Accessed November 15, 2018. http://www.irinnews.org/report/98477/analysis-in-search-of-a-regional-rohingyasolution.

Irish Centre for Human Rights. Crimes against Humanity in Western Burma: The Situation of the Rohingyas. Galway: NUI Galway, 2010.

ISCI. "Genocide of Rohingya in Myanmar May Be Entering New and Deadly Phase." Press release, October 14, 2017. Accessed November 16, 2018. http://statecrime.org/state-crime-research/iscipress-release-genocide-of-rohingya-in-myanmar-may-be-entering-new-and-deadly-phase/.

Keane, Fergal. "EU Lifts Sanctions against Burma." BBC News Europe, April 22, 2013. Accessed December 15, 2017. http://www.bbc.com/news/world-asia-22254493.

Kersten, Mark. Justice in Conflict: The Effects of the International Criminal Court's Interventions on Ending Wars and Building Peace. Oxford: Oxford University Press, 2016. https://doi.org/10.1093/ acprof:0so/9780198777144.001.0001

Marshall, Andrew R.C. and Das, Krishna. "Rohingya Insurgents Declare Temporary Ceasefire Amid Humanitarian Crisis." Reuters, September 9, 2017. Accessed November 15, 2018. https://www.reuters.com/article/us-myanmar-rohingya/rohingya-insurgents-declaretemporary-ceasefire-amid-humanitarian-crisis-idUSKCN1BK07T.

Meixler, Eli. "U.S. Report on Rohingya Stops Short of Calling Myanmar's 'Coordinated' Violence Genocide." Time, September 25, 2018. Accessed November 16, 2018. http://time. com/5405378/state-department-myanmar-rohingya-report/.

Miller, Richard E. and Austin Sarat. "Grievances, Claims, and Disputes: Assessing the Adversary Culture." Law and Society Review 15, no. 3/4 (1981), 525-566. https://doi.org/10.2307/3053502

Nice, Geoffrey and Francis Wade. "Preventing the Next Genocide." Foreign Policy, May 12, 2014.

Nichols, Michelle. "Nine U.N. Security Council Members Ask to Discuss Myanmar Inquiry." Reuters, October 16, 2018. Accessed November 20, 2018. https://www.reuters.com/article/ us-myanmar-rohingya-un/nine-un-security-council-members-ask-to-discuss-myanmarinquiry-idUSKCN1MR07W.

Orsini, Michael. "The Politics Of Naming, Blaming, and Claiming: HIV, Hepatitis C, and the Emergence of Blood Activism in Canada." Canadian Journal of Political Science 35 (2002), 475-498. https://doi.org/10.1017/S0008423902778323

Perlez, Jane. "Death Stalks Muslims as Myanmar Cuts Off Aid." New York Times, May 2, 2014. Accessed November 15, 2018. https://www.nytimes.com/2014/05/03/world/asia/deathstalks-muslims-as-myanmar-cuts-off-aid.html.

Peskin, Victor. International Justice in Rwanda and the Balkans: Virtual Trials and the Struggle for State Cooperation. New York: Cambridge University Press, 2008. https://doi.org/10.1017/ CBO9780511790584

Pitman, Todd and Julie Pace. "Obama Says 'Rohingya,' Displeasing Myanmar Hosts." ABCNews, November 14, 2014. Accessed November 19, 2018. http://abcnews.go.com/International/ wireStory/group-obama-rohingya-myanmar-visit-26904145.

Quintana, Tomás Ojéa. Report of the Special Rapporteur on the Situation of Human Rights in Myanmar. United Nations Human Rights Council. March 6, 2013. UN Doc. A/HRC/22/58. Accessed November 19, 2018. http://www.ohchr.org/Documents/HRBodies/HRCouncil/ RegularSession/Session22/A.HRC.22.58 AUV.pdf. 
Revesz, Rachel. "Doctors Report Horrifying Gang Rape Attacks on Rohingya Women." The Independent, September 25, 2017. Accessed November 15, 2018. http://www.independent. co.uk/news/world/asia/doctors-un-rohingya-muslim-women-refugees-burma-rapesexual-violence-a7965251.html.

Reynolds, Sarnata. "Myanmar Can Keep Rohingya from Starving, but Will It?" CNN World Global Public Square Blog, December7, 2012. Accessed November 15, 2018. http://globalpublicsquare. blogs.cnn.com/2012/12/07/myanmar-can-keep-rohingya-from-starving-but-will-it/.

Savelsberg, Joachim. Representing Mass Violence: Conflicting Responses to Human Rights Violations in Darfur. Oakland: University of California Press, 2015. https://doi.org/10.1525/luminos.4

Schabas, William. Genocide in International Law. Cambridge: Cambridge University Press, 2000.

"Security Council Urges Conditions that Allow Safe Return of Rohingya Refugees." UN News, May 1, 2018. Accessed November 20, 2018. https://news.un.org/en/story/2018/05/1008692.

Sentinel Project for Genocide Prevention. Burma Risk Assessment. September 2013. Accessed December 18， 2017. http://thesentinelproject.org/wp-content/uploads/2013/09/RiskAssessment-Burma-September-2013.pdf.

Smith, Martin. "The Muslim Rohingya of Burma." Presentation at the Conference of Burma Centrum Nederland, December 11, 1995. N.B. Draft only for Consultation. Accessed December 15, 2017. http://www.netipr.org/policy/downloads/19951211-Rohingyas-ofBurma-by-Martin-Smith.pdf.

Spetalnick, Matt and Jason Szep. “U.S. Accuses Myanmar Military of 'Planned and Coordinadted' Rohingya Atrocities." Reuters, September 24, 2018. Accessed November 16, 2018. https://www.reuters.com/article/us-myanmar-rohingya-usa-exclusive/exclusivemyanmar-military-coordinated-atrocities-against-rohingya-u-s-report-idUSKCN1M42DY.

Southwick, Katherine G. "Looming Genocide in Myanmar - And the Silence that Greets It." Talking Points Memo, June 12, 2014. Accessed November 18, 2018. http://talkingpointsmemo.com/ cafe/looming-genocide-in-myanmar-and-the-silence-that-greets-it.

--------. "Myanmar's Democratic Transition: Peril or Promise for the Stateless Rohingya?" Tilburg Law Review 19 (2014), 261-275. https://doi.org/10.1163/22112596-01902025

---------. "Preventing Mass Atrocities against the Stateless Rohingya in Myanmar: A Call for Solutions." Columbia Journal of International Affairs 68, no. 2 (Spring/Summer 2015), 137-156. . "Confronting Genocide in Myanmar: The Urgent Need to Prevent and Protect." Policy Forum, December 2, 2016. Accessed November 18, 2018. https:/www.policyforum.net/ confronting-genocide-myanmar/.

Straus, Scott. "Darfur and the Genocide Debate." Foreign Affairs 84, no. 1 (January-February 2005).

"The Rohingya Refugee Crisis Is the Worst in Decades." The Economist, September 21, 2017. Accessed November 18, 2018. https://www.economist.com/blogs/graphicdetail/2017/09/ daily-chart-13.

Tun, Aung Hla and Jared Ferrie. "Foreign Investment in Myanmar Surges, Office Rents Sizzle." Reuters, September 20, 2013. Accessed November 20, 2018. http://www.reuters.com/ article/2013/09/20/myanmar-investment-idUSL3N0HG0L420130920.

Ulfelder, Jay. “2014 Statistical Risk Assessments.” U.S. Holocaust Memorial Museum Early Warning Project. July 31, 2014. Accessed November 18, 2018. http://cpgearlywarning.wordpress. com/2014/07/31/2014-statistical-risk-assessments/.

Union of Burma. Citizenship Law. Pyithu Hluttaw Law No. 4, 1982.

United Nations. General Assembly Resolution 260, Convention on the Prevention and Punishment of the Crime of Genocide. December 9, 1948. UN Doc. A/RES/260(III).

- Myanmar's Refugee Problem Among World's Worst Humanitarian, Human Rights Crises, Secretary-General Says in Briefing to Security Council. Security Council 8333 ${ }^{\text {rd }}$ Meeting Coverage. August 28, 2018. UN Doc. S/13469.

. Statement of the Special Adviser of the Secretary-General on the Prevention of Genocide on the situation in Myanmar. Press release, March 25, 2013. Accessed December 19, 2017. http:// www.un.org/en/preventgenocide/adviser/pdf/Statement $\% 20$ on $\% 20$ Myanmar $\% 20-\% 20$ 25\%20March\%202013.pdf. 
--------. The Rule of Law and Transitional Justice in Conflict and Post-Conflict Societies, Report of the Secretary-General. August 23, 2004. UN Doc. S/2004/616.

United Nations General Assembly. Resolution 60/1, 2005 World Summit Outcome. October 24, 2005. UN Doc. A/RES/60/1. Accessed November 16, 2018. http://www.un.org/womenwatch/ods/ A-RES-60-1-E.pdf.

-------. Rome Statute of the International Criminal Court. July 17, 1998. UN Doc. A/CONF.183/9. Accessed December 6, 2018. https://www.icc-cpi.int/nr/rdonlyres/ea9aeff7-5752-4f84-be940a655eb30e16/0/rome statute english.pdf.

United Nations High Commission for Refugees. “Operational Update: Bangladesh, 16-31 October 2018." Accessed November 19, 2018. http://reporting.unhcr.org/sites/default/files/ UNHCR\%20Bangladesh\%20-\%20Operational\%20Update\%20-\%2016-31OCT18.pdf.

United Nations Human Rights Council. Report of the international fact-finding mission on Myanmar. UN Doc. A/HRC/39/64. September 12, 2018. Accessed November 16, 2018. https://documentsdds-ny.un.org/doc/UNDOC/GEN/G18/274/54/PDF/G1827454.pdf?OpenElement.

---------. Report of the Detailed Findings of the Independent International Fact-Finding Mission on Myanmar. September 17, 2018. UN Doc. A/HRC/39/CRP.2. Accessed November 16, 2018. https://www.ohchr.org/Documents/HRBodies/HRCouncil/FFM-Myanmar/A HRC 39 CRP.2.pdf.

United Nations Office on Genocide Prevention and the Responsibility to Protect. "Partners." Accessed November 19, 2018. http://www.un.org/en/genocideprevention/partners.html.

United States Department of State. Documentation of Atrocities in Northern Rakhine State. August 2018. Accessed November 16, 2018. https://www.state.gov/documents/organization/286307.pdf.

United States Department of the Treasury. "Treasury Sanctions Commanders of the Burmese

Security Forces for Serious Human Rights Abuses." Press release, August 17, 2018. Accessed November 16, 2018. https://home.treasury.gov/news/press-releases/sm460.

United States Embassy in Burma. "U.S. Treasury Department Office of Public Affairs: Treasury

Implements Termination of Burma Sanctions Program." October 7, 2016. Accessed November 18, 2018. https://mm.usembassy.gov/termination-burma-sanctions-program/.

United States Senator Ben Cardin. "Cardin Labels Burmese Rohingya Crisis 'Genocide,' Presses Administration for Answers." Press statement, October 24, 2017. Accessed November 15, 2018. https://www.cardin.senate.gov/newsroom/press/release/cardin-labels-burmeserohingya-crisis-genocide-presses-administration-for-answers.

-------. "Cardin, McCain Bill on Burma Accountability Passes Senate

Foreign Relations Committee." Press release, February 7, 2018. Accessed November 16, 2018. https://www.cardin.senate.gov/newsroom/press/release/cardin-mccain-bill-on-burmaaccountability-passes-senate-foreign-relations-committee.

“Unprecedented 'Level of Barbarity': UN Genocide Chief on Rohingya Visit." UN News, March 14, 2018. Accessed November 16, 2018. https://news.un.org/en/audio/2018/03/1004962.

“U.S. Says Hold Myanmar Military Leaders Accountable in Rohingya Crisis." Reuters, October 18, 2017. Accessed November 18, 2018. http://www.reuters.com/article/us-myanmarrohingya-tillerson/u-s-says-holds-myanmar-military-leaders-accountable-in-rohingyacrisis-idUSKBN1CN289.

U.S. Secretary of State Colin L. Powell. "The Crisis in Darfur." Testimony, Washington, DC, September 9, 2004. Senate Foreign Relations Committee. Accessed November 19, 2018. https://2001-2009.state.gov/secretary/former/powell/remarks/36042.htm.

"U.S. Withdraws Assistance from Myanmar Military Amid Rohingya Crisis." The Guardian, October 24, 2017. Accessed November 18, 2018. https://www.theguardian.com/world/2017/oct/24/ us-withdraws-assistance-from-myanmar-military-amid-rohingya-crisis.

Weithoff, Carolyn. "Naming, Blaming, and Claiming in Public Disputes: The 1998 Maine Referendum on Civil Rights Protection for Gay Men and Lesbians." Journal of Homosexuality 44 (2003), 61-82. https://doi.org/10.1300/J082v44n01 04

Zarni, Maung and Alice Cowley. "The Slow-Burning Genocide of Myanmar's Rohingya." Pacific Rim Law and Policy Journal 23, no. 3 (June 2014), 681-752. 
Zarni, Maung. Featuring Tomás Ojéa Quintana. “UN's Quintana: 'elements of genocide' against Myanmar's Rohingya." Remarks presented at London Conference on Decades of Persecution and Destruction of Myanmar's Rohingya, London, April 28, 2014. Accessed November 18, 2018. https://www.youtube.com/watch?v=Mpn5Amp ZfQ.

Zengerle, Patrick and Matt Spetalnick. “U.S. Weighs Calling Myanmar's Rohingya Crisis 'Ethnic Cleansing."' Reuters, October 25, 2017. Accessed November 18, 2017. https://uk.reuters. com/article/uk-myanmar-rohingya-usa/u-s-weighs-calling-myanmars-rohingya-crisisethnic-cleansing-idUKKBN1CT2RT. 